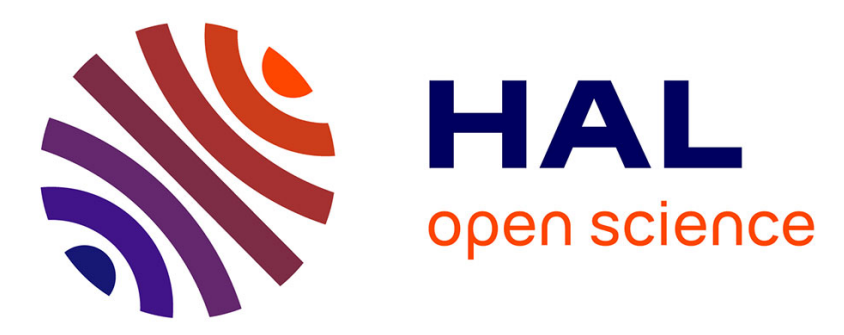

\title{
Light regulation of resistance to oxidative damage and magnetic crystal biogenesis in Magnetospirillum magneticum mediated by a Cys-less LOV-like protein
} Haitao Chen, Kefeng Li, Yao Cai, Pingping Wang, Weimin Gong, Long-Fei $\mathrm{Wu}$, Tao Song

\section{To cite this version:}

Haitao Chen, Kefeng Li, Yao Cai, Pingping Wang, Weimin Gong, et al.. Light regulation of resistance to oxidative damage and magnetic crystal biogenesis in Magnetospirillum magneticum mediated by a Cys-less LOV-like protein. Applied Microbiology and Biotechnology, 2020, 104 (18), pp.7927-7941. 10.1007/s00253-020-10807-5 . hal-02993019

\section{HAL Id: hal-02993019 \\ https://hal-amu.archives-ouvertes.fr/hal-02993019}

Submitted on 23 Jun 2021

HAL is a multi-disciplinary open access archive for the deposit and dissemination of scientific research documents, whether they are published or not. The documents may come from teaching and research institutions in France or abroad, or from public or private research centers.
L'archive ouverte pluridisciplinaire HAL, est destinée au dépôt et à la diffusion de documents scientifiques de niveau recherche, publiés ou non, émanant des établissements d'enseignement et de recherche français ou étrangers, des laboratoires publics ou privés. 


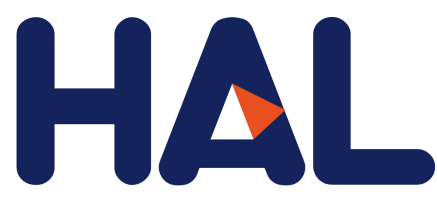

archives-ouvertes

\section{Light regulation of resistance to oxidative damage and magnetic crystal biogenesis in Magnetospirillum magneticum mediated by a Cys-less LOV-like protein}

Haitao Chen, Kefeng Li, Yao Cai, Pingping Wang, Weimin Gong, Long-Fei $\mathrm{Wu}$, Tao Song

\section{To cite this version:}

Haitao Chen, Kefeng Li, Yao Cai, Pingping Wang, Weimin Gong, et al.. Light regulation of resistance to oxidative damage and magnetic crystal biogenesis in Magnetospirillum magneticum mediated by a Cys-less LOV-like protein. Applied Microbiology and Biotechnology, Springer Verlag, 2020, 104 (18), pp.7927-7941. 10.1007/s00253-020-10807-5 . hal-02999410

\section{HAL Id: hal-02999410 \\ https://hal.archives-ouvertes.fr/hal-02999410}

Submitted on 20 Dec 2020

HAL is a multi-disciplinary open access archive for the deposit and dissemination of scientific research documents, whether they are published or not. The documents may come from teaching and research institutions in France or abroad, or from public or private research centers.
L'archive ouverte pluridisciplinaire HAL, est destinée au dépôt et à la diffusion de documents scientifiques de niveau recherche, publiés ou non, émanant des établissements d'enseignement et de recherche français ou étrangers, des laboratoires publics ou privés. 
4

5 Haitao Chen ${ }^{1,2,3}$, Kefeng $\mathrm{Li}^{1,4}$, Yao $\mathrm{Cai}^{5}$, Pingping Wang ${ }^{1,3}$, Weimin $\mathrm{Gong}^{6}$, Long-Fei $\mathrm{Wu}^{3,7}$ *, Tao 6 Song $^{1,2,3}$ *

7

$8 \quad{ }^{1}$ Beijing Key Laboratory of Biological Electromagnetism, Institute of Electrical Engineering, Chinese 9 Academy of Sciences, Beijing 100190, China;

$10{ }^{2}$ University of Chinese Academy of Sciences, Beijing 100049, China;

$11{ }^{3}$ France-China International Laboratory of Evolution and Development of Magnetotactic Multicellular
Light regulation of resistance to oxidative damage and magnetic crystal biogenesis in Magnetospirillum magneticum mediated by a Cys-less LOV-like protein ${ }^{4}$ Shandong Sport University, Jinan 250102, China;

${ }^{5}$ Key Laboratory of Earth and Planetary Physics, Institute of Geology and Geophysics, Chinese Academy of Sciences, Beijing 100029, China;

${ }^{6}$ Hefei National Laboratory for Physical Sciences at the Microscale, School of Life Sciences, University of Science and Technology of China, Hefei, Anhui 230027, China;

${ }^{7}$ Aix Marseille University, CNRS, LCB, Marseille F-13402, France.

* Correspondences:

Dr. Long-Fei Wu

wu@imm.cnrs.fr

Dr. Tao Song

songtao@mail.iee.ac.cn

Tel. 86-10-82547164

Fax 86-10-82547164

ORCID iD: 0000-0001-7070-7819 


\section{Abstract}

Light-oxygen-voltage (LOV) proteins are ubiquitous photoreceptors that can interact with other regulatory proteins and then mediate their activities, which results in cellular adaptation and subsequent physiological changes. Upon blue-light irradiation, a conserved cysteine (Cys) residue in LOV covalently binds to flavin to form a flavin-Cys adduct, which triggers a subsequent cascade of signal transduction and reactions. We found a group of natural Cys-less LOV-like proteins in magnetotactic bacteria (MTB) and investigated its physiological functions by conducting research on one of these unusual LOV-like proteins, Amb2291, in Magnetospirillum magneticum. In-frame deletion of amb2291 or site-directive substitution of alanine-399 for Cys mutants impaired the protective responses against hydrogen peroxide, thereby causing stress and growth impairment. Consequently, gene expression and magnetosome formation were affected, which led to high sensitivity to oxidative damage and defective phototactic behaviour. The purified wild-type and A399C-mutated LOV-like proteins had similar LOV blue-light response spectra, but Amb2291 ${ }^{\mathrm{A} 399 \mathrm{C}}$ exhibited a faster reaction to blue light. We especially showed that LOV-like protein Amb2291 plays a role in magnetosome synthesis and resistance to oxidative stress of AMB-1 when this bacterium was exposed to red light and hydrogen peroxide. This finding expands our knowledge of the physiological function of this widely distributed group of photoreceptors and deepens our understanding of the photoresponse of MTB.

Key words: LOV, magnetotactic bacteria, Amb2291, oxidative stress, reactive oxygen species. 


\section{$52 \quad$ Key points}

53 We found a group of Cys-less light-oxygen-voltage (LOV) photoreceptors in magnetotactic bacteria,

54 which prompted us to study the light-response and biological roles of these proteins in these 55 non-photosynthetic bacteria.

56

57 The Cys-less LOV-like protein participates in the light-regulated signalling pathway and improves resistance to oxidative damage and magnetic crystal biogenesis in Magnetospirillum magneticum.

59

60 This result will contribute to our understanding of the structural and functional diversity of the 61 LOV-like photoreceptor and help us understand the complexity of light-regulated model organisms.

62 


\section{Introduction}

Most bacteria must cope with frequent changes in their environment; hence, they developed various mechanisms to sense and respond to external stimuli for growth and survival. Bacteria can use light as a source of energy when exposed to it, but they can also be damaged by ultraviolet (UV) radiation or light-generated reactive oxygen species (ROS) (Metz et al. 2012). Different types of photoreceptors, such as light-oxygen-voltage (LOV) sensing protein, photoactive yellow protein, phytochrome, sensor of blue light using flavin adenine dinucleotide, cryptochromes, and sensory rhodopsin, are involved in bacterial photosensing (Braatsch and Klug 2004; Losi 2007; Purcell and Crosson 2008; Spudich 2006; Wilde and Mullineaux 2017).

Photoreceptor LOV belongs to a subset of the Per-Arnt-Sim (PAS) family that utilizes internally bound flavin chromophores to sense changes in blue light or redox state (Pudasaini et al. 2017; Taylor and Zhulin 1999; Wu et al. 2013). The flavin chromophore binds non-covalently to LOV in a dark environment. Flavin photon absorption results in the formation of a flavin-C4(a)-cysteinyl adduct with a conserved cysteine (Cys) residue on the PAS-motif, thereby initiating a cascade of structural rearrangements within the LOV core, which are propagated to the domain boundaries (Pudasaini et al. 2015; Salomon et al. 2000). LOV proteins are widely distributed in bacteria. The first bacterial LOV protein from Bacillus subtilis, YtvA (Akbar et al. 2001), was initially reported as a positive regulator of general stress response (GSR). It binds to flavin mononucleotide (FMN) and undergoes a photocycle similar to that of the LOV domains of the plant phototropins (Losi et al. 2002). In Dinoroseobacter shibae, a blue-light photoreceptor of the LOV superfamily ( $D s \mathrm{LOV})$ regulates photopigment synthesis (Endres et al. 2015). Purcell et al. suggested that bacterial LOV domain proteins may function as redox sensors via flavin chromophore itself (Purcell et al. 2010). Furthermore, the data hint at a link between RsLOV in Rhodobacter sphaeroides, carbohydrate metabolism and chemotaxis, and the response of cells to photooxidative stress (Metz et al. 2012). The blue-light-modulating activity of RsLOV and Rs AppA is intended to maximize photosynthesis under favourable conditions and to minimize photooxidative damage (Losi et al. 2015; Metz et al. 2012). In Brucella abortus, LOVhK is a cognate sensor histidine kinase of PhyR that functions as a stress sensor (and GSR pathway activator). GSR can be activated by red and blue lights and many other stimuli. Deletion of LOVhK severely impairs cell survival under defined conditions of oxidative and acid stresses (Kim et al. 2014). In addition, 
blue-light inhibition of Listeria monocytogenes growth is mediated by ROS and is influenced by $\sigma^{\mathrm{B}}$ and the blue-light sensor Lmo0799 (O'Donoghue et al. 2016).

Previous research has found that replacement of the conserved adduct-forming Cys with alanine (Ala) abolishes the photochemical reaction of LOV (Salomon et al. 2000). Recently, Yee et al. found that by removing the conserved Cys, the LOV protein still undergoes light-induced photoreaction and signal transduction through the signalling capability of neutral semiquinone (NSQ), which is photoreduced from flavin (Yee et al. 2015). Interestingly, naturally occurring LOV proteins with proline (Pro) at the position of the adduct-forming Cys residue can still respond to light. Additional studies are needed to determine whether the light-induced naturally Cys-less LOV undergoing signal transduction is widespread. Notably, we found a group of magnetotactic bacteria (MTB) that possess Cys-less LOV-like proteins in which the Ala occupied the position of the adduct-forming Cys. Moreover, these LOV-like proteins contain an N-terminal putative transmembrane domain. MTB can synthesize intracellular membrane-enclosed, nanosized, and chain-arranged magnetite and/or greigite crystals called magnetosomes (Komeili 2007; Spring and Bazylinski 2002). Magnetosome chains are the magnetic sensors in MTB that act as an internal compass needle and help in the rapid orientation along the geomagnetic field, a behaviour known as magnetotaxis (Faivre and Schuler 2008; Frankel and Blakemore 1989; Komeili 2012). In addition to the magnetotaxis function, magnetosomes in Magnetospirillum gryphiswaldense MSR-1 exhibit peroxidase-like activity that reduces intracellular levels of ROS (Guo et al. 2012). Moreover, light irradiation can help M. magneticum AMB-1 cells eliminate intracellular levels of ROS (Li et al. 2017). Other studies also revealed the photoresponses of magnetotaxis in some MTB (de Melo and Acosta-Avalos 2017; Li et al. 2017; Qian et al. 2019; Shapiro et al. 2011; Zhou et al. 2011). It is unknown whether and what kind of photoreceptor is involved in this process. Analysis of AMB-1 genome reveals an unusual LOV-like photoreceptor, Amb2291, of which the expected conserved adduct-forming Cys at the location of 399 was actually replaced with Ala. To assess the function of the LOV-like protein, we mutated amb2291 and analysed the effects of irradiation and hydrogen peroxide $\left(\mathrm{H}_{2} \mathrm{O}_{2}\right)$-induced oxidative stress (photo-oxidative stress) on cell growth and magnetosome biosynthesis in AMB-1 wild-type (WT) cells and amb2291 mutants. Quantitative reverse transcription polymerase chain reaction (qRT-PCR) and dichlorofluorescin diacetate (DCFH-DA) methods were used to analyse the requirement of amb2291 in regulating the 
expression of antioxidant genes as well as magnetosome formation genes, which scavenge intracellular ROS under photooxidative stress conditions. In addition, deletion of amb2291 or A399C substitution affects the phototactic behaviour of AMB-1, which further confirms the role of Amb2291 in antioxidant damage. Moreover, we purified the Amb2291 and A399C mutant proteins and analysed their photochemical properties. This study contributes to the elucidation of the photoreaction mechanism and deepens the understanding of the photoresponse of MTB.

\section{Materials and Methods}

\section{Strains and culture conditions}

Escherichia coli DH5 $\alpha$ was used for general cloning. The WM3064 of E. coli was used for intergeneric conjugation between E. coli and M. magneticum. E. coli strains were grown in LB medium supplemented with apramycin $(50 \mu \mathrm{g} / \mathrm{mL})$ or kanamycin $(50 \mu \mathrm{g} / \mathrm{mL})$. M. magneticum AMB-1 strains (ATCC 700264) were grown on modified enriched Magnetospirillum growth medium comprising 5 $\mathrm{mL}$ of $0.01 \mathrm{M}$ ferric quinate, $0.68 \mathrm{~g}$ of potassium phosphate, $0.12 \mathrm{~g}$ of sodium nitrate, $0.74 \mathrm{~g}$ of succinic acid, $0.05 \mathrm{~g}$ of L-Cys-HCl, $0.2 \mathrm{~g}$ of polypeptone, and $0.1 \mathrm{~g}$ of yeast extract. In addition, 15 $\mu \mathrm{g} / \mathrm{mL}$ apramycin or kanamycin was used for plasmid selection (Matsunaga et al. 2005; Matsunaga et al. 1991; Yang et al. 2001). M. magneticum AMB-1 strains were cultured using a $100 \mathrm{~mL}$ Schott flask bottle or a $15 \mathrm{~mL}$ cell culture flask and incubated at $30^{\circ} \mathrm{C}$.

\section{Identification of the Amb2291 sequence}

Amb2291 was identified in the M. magneticum AMB-1 genomic database BLAST (Matsunaga et al. 2005). Amino acid sequences were aligned using DNAMAN. Domain was analysed by SMART (http://smart.embl-heidelberg.de). The protein accession numbers were as follows: M. magneticum AMB-1 (WP_070108660.1, Amb2291); M. magnetotacticum MS-1 (KIL98983.1); M. gryphiswaldense MSR-1 (WP_106001729.1); Magnetospirillum sp. ME-1 (WP_085373061.1); Magnetospirillum sp. XM-1 (WP_068434569.1); H. hochstenium (WP_008581736.1); Microcoleus vaginatus (WP_006631677.1); Populus trichocarpa (XP_002315641.1); Nectria (XP_003042477.1); Allium cepa (ACT22763.1); Asticcacaulis sp. YBE204 (WP_023462395.1); Azospirillum halopraeferens (WP_029010434.1); B. subtilis (O34627.1); Crocosphaera watsonii (WP_007308072.1); Gluconobacter frateurii (WP_023942432.1); Granulicella mallensis (WP_014265984.1); B. abortus 
(WP_002971240.1); Methylocystis rosea (WP_018406994.1); Roseobacter denitrificans (WP_011568342.1); Avena sativa (PDB 2V0U); Rhodobacter sphaeroides (WP_009562854.1); and Dinoroseobacter shibae (WP_044027762.1).

\section{Purification of protein}

The conserved soluble fragment (residues 351-714) of amb2291 or amb2291 ${ }^{A 399 C}$ was cloned into the pET28a plasmid with N-terminal His6-SUMO-tagged fusion proteins. These proteins were expressed in E. coli BL21 (DE3) cells and purified as previously described (Li et al. 2019). The expression levels of Amb2291 variants were induced with $10 \mu \mathrm{M}$ isopropyl- $\beta$-D-1-thiogalactopyranoside for $16 \mathrm{~h}$ at $16^{\circ} \mathrm{C}$ in the dark. For cell lysis, the soluble extract was filtered and incubated with $5 \mathrm{mM}$ FMN on ice for $20 \mathrm{~min}$. After nickel chelate affinity chromatography, the proteins were further purified by size exclusion chromatography on Superdex 200 column in Tris buffer $(10 \mathrm{mM}$ Tris/Cl, $200 \mathrm{mM} \mathrm{NaCl}, \mathrm{pH}$ 8.0). All experiments were carried out in the dark.

\section{Genetic manipulation of AMB-1}

All plasmids and primers used in the study are listed in Tables S1 and S2. Deletion of 2045 nucleotides of Amb2291 (81-2125) was conducted by a CRISPR-Cas9 system using plasmid pCRISPomyces-2 (Cobb et al. 2015). The first step in constructing plasmid pCRISPR-sgRNAamb2291 was to select the proper sgRNA sequence. sgRNA carrying the $20 \mathrm{nt}$ specific targeting sequence was synthesized (Sangon Biotech, China) and inserted into the pCRISPomyces-2 through a BbsI site (Chen et al. 2018; Xie et al. 2014). A $2.0 \mathrm{~kb}$ HDR DNA fragment of the editing template was amplified from the purified genomic DNA of AMB-1 and inserted into the pCRISPR-sgRNAamb2291 with the XbaI restriction enzyme.

The vector used for the allelic exchange of WT amb2291 for amb2291 ${ }^{A 399 C}$ was constructed as follows. PCR amplification of amb2291 with $1.0 \mathrm{~kb}$ upstream and downstream sequences was conducted using Q5 high-fidelity polymerase (NEB, United States). The resulting $4.2 \mathrm{~kb}$ fragment was incorporated into pBBRI-mcs2. To prevent the sgRNA of the CRISPR plasmid from cutting the replaced amb2291 $1^{A 399 C}$ in AMB-1, we inserted a nonsense mutation into the sequence of PAM and the sgRNA sequence in the $a m b 2291^{A 399 C}$ fragment, so that sgRNA will not recognize and Cas9 will not cut $a m b 2291^{A 399 C}$ in 
AMB-1, guaranteeing the construction of the $a m b 2291^{A 399 C}$ strain. Site-directed mutagenesis of the resulting plasmid by using the NEBuilder HiFi DNA assembly reaction protocol was conducted to introduce the A399C, PAM, and sgRNA sequences of the nonsense mutation (PAM: CCT to aCT and sgRNA sequence: GTTCACCCTGCCCATGACCC to aTTCACCCTGCCCATGACCC). The site-directed $4.2 \mathrm{~kb}$ fragment was inserted into the plasmid pCRISPR-sgRNAamb2291 by using the same method as above.

All pCRISPR plasmids were transformed into the E. coli strain WM3064 by chemical transformation and transferred into AMB-1 through conjugation (Chen et al. 2018; Philippe and Wu 2010). All deletions were verified by PCR and sequencing.

\section{Irradiation experiment and $\mathrm{H}_{2} \mathrm{O}_{2}$-induced oxidative stress in AMB-1}

We investigated the effect of photooxidative stress on the growth and magnetosome biomineralization of AMB-1 cells. All cells were grown with the exposure to $20 \mu \mathrm{mol}$ photons $/ \mathrm{m}^{2} / \mathrm{s}$ from $625 \mathrm{~nm}$ or 450 nm LED light (Fig. S1a, Ouyingzhaoming, China) and were cultured in medium containing $\mathrm{H}_{2} \mathrm{O}_{2}$ at 0 , 5, 7.5, 10, and $15 \mu \mathrm{M}$. In general, light exerts a certain decomposition effect on $\mathrm{H}_{2} \mathrm{O}_{2}$. Therefore, by using the $\mathrm{H}_{2} \mathrm{O}_{2}$ Quantitative Assay Kit (Sangon Biotech, China), medium with $15 \mu \mathrm{M} \mathrm{H}_{2} \mathrm{O}_{2}$ was used to analyse the $\mathrm{H}_{2} \mathrm{O}_{2}$ concentration changes versus the illumination time. The medium contains no iron ions to prevent the detection of $\mathrm{H}_{2} \mathrm{O}_{2}$ (Fig. S1b). We also detected the change in the $\mathrm{H}_{2} \mathrm{O}_{2}$ concentration in the dark, and the value remained unchanged within $20 \mathrm{~h}$. The optical density (OD) and cellular magnetisms (Cmag) of exponentially growing cultures were measured at $600 \mathrm{~nm}$ under a $4.5 \mathrm{mT}$ homogeneous magnetic field with a UV-visible spectrophotometer (Unico UV-2800, United States) and an electromagnetic system (Schüler et al. 1995; Zhao et al. 2007).

\section{Quantitative RT-PCR assay}

The procedure for qRT-PCR was based on a previously described general protocol (Chen et al. 2018). Analysis was performed with cells in the plateau phase. Total RNA was extracted using an RNAeasy Plus Minikit (Qiagen, Germany). Single-strand cDNA was synthesized with a reverse transcription kit (Takara, Japan). qRT-PCR assay was performed with the SYBR Green Real-time PCR Mix (Thermo Fisher Scientific, United States) on an ABI QuantStudio 6 Flex Real-time PCR System (Applied 
Biosystems, United States). The relative expression level was calculated by the $2_{\mathrm{T}}^{-\Delta \Delta \mathrm{C}}$ method using the threshold cycle of 16S rRNA for normalization (Livak and Schmittgen 2001). The experiment was repeated at least thrice, with each sample run in triplicate. All primers used for probing each gene in this study are listed in Table S2.

\section{Detection of ROS generation}

Intracellular ROS levels were analysed using the DCFH-DA method (He and Hader 2002; Wang et al. 2013). After irradiation and $\mathrm{H}_{2} \mathrm{O}_{2}$ induction, the cells grew to the late stage of exponential growth. Then, $2 \mathrm{~mL}$ of bacterial culture was immediately added to $10 \mu \mathrm{L}$ of $10 \mathrm{mM}$ DCFH-DA and incubated at $37^{\circ} \mathrm{C}$ for $30 \mathrm{~min}$ in the dark. The cells were centrifuged at $12,000 \mathrm{rpm}$ for $6 \mathrm{~min}$ and washed thrice with a PBS buffer. The fluorescence of all samples was measured using a fluorescence spectrophotometer (Hitachi F-4500, Japan) at an excitation wavelength of $485 \mathrm{~nm}$ and emission wavelengths of 500-600 $\mathrm{nm}$.

\section{Motility and phototactic behaviour analyses of AMB-1}

AMB-1 motility behaviour was analysed at a frame rate of 33 fps by using a long working distance $40 \times$ Olympus objective. Cells $(10 \mu \mathrm{L})$ were observed on a glass slide with an Olympus microscope. Single cells were tracked, and the average swimming velocities were calculated using the MTrackJ plugin for ImageJ (Meijering et al. 2012; Murat et al. 2015; Zhang et al. 2017). Phototactic behaviour was quantitatively analysed using a modified mini MTB collection vessel as previously described (Li et al. 2017). The cultures $(80 \mathrm{~mL})$ with and without $\mathrm{H}_{2} \mathrm{O}_{2}$ induction were pooled into the reservoir and into the collecting tube. A microaerobic band formed after $30 \mathrm{~min}$ of growth in the dark prior to conducting the phototactic experiment. The upper interface of the microaerobic zone is parallel to the collection tube. Then, the device was placed in a cassette, where the collection tube was parallelly exposed to the light beam. Control experiments were conducted in the dark. After 30 min of collection, we measured the $\mathrm{OD}$ in the collecting tube and reservoir $\left(\mathrm{OD}_{\text {collecting tube }}\right.$ and $\mathrm{OD}_{\text {reservoir }}$, respectively). The ratio of $\left(\mathrm{OD}_{\text {collecting tube }}-\mathrm{OD}_{\text {reservoir }}\right) / \mathrm{OD}_{\text {reservoir }}$ was used to determine the relative numbers of phototactic cells.

\section{Spectrophotometry analyses}

The absorbance spectra of purified Amb2291 WT and mutant proteins were determined from $700 \mathrm{~nm}$ to 
$250 \mathrm{~nm}$ at room temperature using a UV-visible spectrophotometer. Assays were recorded either in the dark or after exposure to a blue LED lamp $(450 \mathrm{~nm})$ or red LED lamp (625 nm) (Ouyingzhaoming,

245 China). Fluorescence excitation and emission spectra were recorded at room temperature with a fluorescence spectrophotometer (Hitachi F-4500, Japan). The emission wavelength was $530 \mathrm{~nm}$, and the excitation was at $450 \mathrm{~nm}$.

\section{Statistical analysis}

All statistical analyses were performed using SPSS 22.0 (SPSS, IBM, United States). Hierarchical clustering analysis (HCA) was performed to analyse the values of $\mathrm{OD}_{600}$ and $\mathrm{Cmag}$. ROS values and the transcription-level results were analysed using two-tailed Student's t-test. Mann-Whitney U-test was used to analyse phototactic behaviour. One-way analysis of variance was used to investigate the difference in velocities under $\mathrm{H}_{2} \mathrm{O}_{2}$-induced oxidative stress. Each experiment was repeated three times or more. All data were expressed as the mean \pm standard deviation. In all cases, statistical tests were considered significant at $p<0.05$.

\section{Results}

\section{Genomes of Magnetospirillum sp. encode a group of natural Cys-less LOV-like proteins}

Genomic analysis allowed us to identify the amb2291 as a CDS coding a LOV-like protein in AMB-1. This 713-residue protein contains the LOV-like domain encompassing PAS and PAC domains, histidine kinase, and histidine kinase-like ATPase (Fig. 1a). Notably, this LOV domain includes the key residues of the canonical LOVs, such as the signalling relevant glutamine $(\mathrm{Gln})$, the asparagines that interact with the polar side of the isoalloxazine ring, and the arginines that interact with the phosphate moiety of the flavin (Fedorov et al. 2003), but it does not contain the Cys in the highly conserved motif GXNCRFLQ (Fig. 1b). The conserved Cys residue is involved in the photochemical generation of a flavin-Cys adduct upon blue-light absorption by the flavin in LOV photoreceptors (Briggs 2007; Christie et al. 1999). At the Cys position, an Ala substitutes for the strictly conserved Cys in the LOV domain of Amb2291 and the homologues from other Magnetospirium sp. strains MS-1, MSR-1, ME-1, and XM-1 (Fig. 1b). In other naturally occurring Cys-less LOV, this position can be Pro, glycine (Gly), or lysine (Lys). This observation would challenge the photoresponse and physiological function of this group of natural Cys-less, LOV-like proteins in magnetospirilla. Moreover, all Magnetospirillum sp. 
LOV-like full-length proteins contain transmembrane domains with 1 to 3 predicted transmembrane segments. To assess the function of this group of LOV-like proteins, we constructed an amb2291 deletion mutant and a site-directed A399C mutant in AMB-1 (substitution of Cys for Ala 399) (as described in "Materials and Methods").

\section{Characteristics of recombinant $\mathrm{Amb2291}$ and $\mathrm{Amb2291}^{\mathrm{A399}}$ proteins}

To verify whether the Cys-less Amb2291 has the characteristics of LOV and to investigate the effect of light illumination of Amb2291 or variant, the soluble LOV-like sensory domain of Amb2291 and Amb2291 ${ }^{\mathrm{A} 399 \mathrm{C}}$ from residues 351 to 714 (Fig. S2) were expressed in E. coli BL21 (DE3) as N-terminal His6-SUMO-tagged protein and purified via nickel chelate affinity, SUMO protease treatment and size exclusion chromatography. Recombinant proteins on denaturing gels of electrophoresis have a yellow colour and an apparent size of $\sim 40 \mathrm{kDa}$ (Fig. S3). Based on the peak position of the elution profiles of a Superdex 200-size exclusion column, Amb2291 and Amb2291 ${ }^{\text {A399C }}$ displayed a molecular weight of approximately $80 \mathrm{kDa}$ (Fig. S3), thereby suggesting the dimer property of these proteins in solution. Amb2291 and Amb2291 ${ }^{\text {A399C }}$ exhibited a broad absorption band in the blue region that might be composed of sharp peaks near 449 and $475 \mathrm{~nm}$ and a shoulder near $420 \mathrm{~nm}$, revealing a mixture of oxidized $(450 \mathrm{~nm})$ states of FMN. In addition, the absorption spectrum of Amb2291 had a double-peak structure at 361 and $375 \mathrm{~nm}$, whereas the component at $361 \mathrm{~nm}$ was reduced to a minor shoulder in the absorption spectrum of Amb2291 ${ }^{\mathrm{A} 399 \mathrm{C}}$. The major UV-A absorption maximum occurred at $378 \mathrm{~nm}$ (Fig. 2a). Fig. $2 b$ and $c$ show the fluorescence emission and excitation spectra of the Amb2291 and Amb2291 ${ }^{\text {A399C }}$ proteins, respectively. Compared with Amb2291, the fluorescence emission spectrum maximum of A399C mutant shows a redshift of $4 \mathrm{~nm}$. The highest peaks of Amb2291 and Amb2291 ${ }^{\mathrm{A} 399 \mathrm{C}}$ proteins are at 529 and $533 \mathrm{~nm}$, respectively, and those in the excitation spectrum are at $467 \mathrm{~nm}$. Thus, both Amb2291 and Amb2291 ${ }^{\mathrm{A} 399 \mathrm{C}}$ demonstrated the characteristic properties for the LOV core, but a slight difference was obvious between the two chromophore binding domains.

Fig. 3 shows that dark-state LOV proteins contain an oxidized flavin cofactor that maximally absorbs blue light at $449 \mathrm{~nm}$ in the ground state. Blue-light irradiation results in the bleaching of the ground state and in the formation of a photoproduct, and absorption increased at $390 \mathrm{~nm}$ (Fig. 3a, b). The results show a faster reaction of the A399C mutant to blue-light illumination compared with the WT 
strain (Fig. 3c), demonstrating the efficiency of adduct formation in the presence of Cys. Moreover, similar to the BAT P188C mutant of H. hochstenium (Yee et al 2015), Amb2291 and Amb2291 ${ }^{\mathrm{A} 399 C}$ appear to form the hydroquinone (HQ) directly with little NSQ intermediate observed on our observed time scale.

\section{Effects of $a m b 2291$ deletion on cell growth under conditions with photooxidative stress}

To investigate the role of Amb2291, we performed a CRISPR-Cas9-based gene knockout experiment to construct in-frame deletion of amb2291 as described in the "Materials and Methods" section. The effects of photooxidative stress on cell growth in AMB-1 WT cells and $\Delta a m b 2291$ mutant were analysed. AMB-1 cells were treated with different concentrations of $\mathrm{H}_{2} \mathrm{O}_{2}$ and immediately incubated for $20 \mathrm{~h}$ under multiple light ranges (red light $625 \mathrm{~nm}$ or blue light $450 \mathrm{~nm}, 20 \mu \mathrm{mol}$ photons $/ \mathrm{m}^{2} / \mathrm{s}$ ) or dark conditions. OD at $600 \mathrm{~nm}$ was measured to evaluate the oxidative stress effect on growth.

As shown in Fig. 4, the OD values can be grouped into clusters a, b, and c by using the HCA method when the squared Euclidean distance is equal to 4 . Without irradiation in the dark, the OD of both AMB-1 WT cells and $\triangle a m b 2291$ mutant decreased with the increase in the $\mathrm{H}_{2} \mathrm{O}_{2}$ concentration in the growth media starting from $5 \mu \mathrm{M}$ (Fig. 4, black curves). The OD of AMB-1 WT cells drastically decreased from $10 \mu \mathrm{M} \mathrm{H} \mathrm{H}_{2} \mathrm{O}_{2}$ and continued to decrease with increasing $\mathrm{H}_{2} \mathrm{O}_{2}$ concentration under blue-light irradiation, while the OD of $\triangle a m b 2291$ mutant decreased from $7.5 \mu \mathrm{M}$ (group c, blue curves in Fig. 4). The reason may be that blue light induces the formation of ROS that adds to the stress induced by $\mathrm{H}_{2} \mathrm{O}_{2}$ addition. However, red-light irradiation abolished the deleterious effect of $\mathrm{H}_{2} \mathrm{O}_{2}$ on the WT cells at all analysed concentrations (Fig. 4, red curve, group a). Interestingly, the sensitivity of the $\Delta a m b 2291$ mutant to $\mathrm{H}_{2} \mathrm{O}_{2}$ under the red-light irradiation showed no significant change compared with darkness treatment as well as WT cells under darkness (Fig. 4, red dashed-line, group b). Collectively, these results revealed that red light protects the AMB-1 WT cells from the deleterious effect of $\mathrm{H}_{2} \mathrm{O}_{2}$-generated oxidative stress, which was dependent on the function of Amb2291. For better understanding the response of AMB-1 to photooxidative stress, red light was the main light source in the following studies. 
To investigate the functional differences between Amb2291 and Amb2291 ${ }^{\mathrm{A} 99 \mathrm{C}}$, we constructed an allelic exchange of WT amb2291 for the amb2291 ${ }^{A 399 C}$ mutant. By qRT-PCR analysis, we observed that red-light irradiation increased the expression of the amb2291 gene in WT cells, regardless of the $\mathrm{H}_{2} \mathrm{O}_{2}$ treatment (Fig. 5). The deletion of the amb2291 gene from 81 to 2125 nucleotides substantially enhanced amb2291 expression, especially under the conditions of red-light irradiation and the presence of $\mathrm{H}_{2} \mathrm{O}_{2}(p<0.01)$, since the first 80 nucleotides of amb2291 were still kept in $\Delta a m b 2291$, but the transcription level is higher than that of WT and $a m b 2291^{A 399 C}$. By contrast, site-specific substitution for the conserved Cys, amb2291 $1^{A 399 C}$ mutation displayed the same phenotype of the WT strain. These results unveil the autoregulation of amb2291 to a certain extent of the transcription level compared with the higher transcription level in $\Delta a m b 2291$ caused by the incomplete function of amb2291. In addition, the conservation of Ala 399 is not required for the autoregulation, although it is indispensable for the attenuation of photooxidative stress.

\section{Effect of $\mathrm{H}_{2} \mathrm{O}_{2}$ and light illumination on magnetosome formation in AMB-1 cells}

We analysed the effect of photooxidative stress on magnetosome formation by measuring Cmag in AMB-1 WT, $\triangle a m b 2291$, and $a m b 2291^{A 399 C}$ mutant cells (Schüler et al. 1995; Zhao et al. 2007). By the HCA method, the results showed that Cmag can be divided into clusters (a) and (b) when the squared Euclidean distance is equal to 4 (Fig. 6a). The Cmag value in WT cells under red-light irradiation and with $\mathrm{H}_{2} \mathrm{O}_{2}$-induced oxidative stress formed cluster a, which was higher than all those under the other conditions. This result suggested that Amb2291, red light, and oxidative stress contributed to the maximum synthesis of magnetosomes.

We previously reported that magnetosome-formation-associated genes mms 13 , mms 6 , and $m m s F$ significantly responded to visible light ( $\mathrm{Li}$ et al. 2017). To investigate the mechanism by which photooxidative stress influences magnetosome formation in AMB-1 WT and mutant cells, we also performed qRT-PCR to detect the expression levels of mms13, mms6, and mmsF. After $20 \mathrm{~h}$ of illumination, the expression levels of $m m s 13$ and $m m s F$ were significantly upregulated in WT cells and amb2291 ${ }^{A 399 C}$ mutants compared with their dark controls (Fig. 6b, d, $p<0.05$ ). Importantly, red- light illumination led to significant upregulation of $m m s 13, m m s 6$, and $m m s F$ in WT cells compared with $\triangle a m b 2291$ and amb2291 ${ }^{A 399 C}$ strains (Fig. 6b, c and d, $p<0.05$ ). $\mathrm{H}_{2} \mathrm{O}_{2}$ treatment also led to significant 
upregulation of $m m s 13$ in WT cells compared with $\triangle a m b 2291$ or amb2291 $1^{A 399 C}$ mutant strains (Fig. 6b, $p<0.05)$. mms6 expression was significantly downregulated in the $\mathrm{H}_{2} \mathrm{O}_{2}$ treatment of $\Delta a m b 2291$ strains compared with dark controls (Fig. 6c, $p<0.05$ ). Red light improved the magnetosome synthesis of WT AMB-1 cells, which was related to the function of Amb2291.

amb2291 regulates the expression of antioxidant genes and helps AMB-1 scavenge intracellular ROS

At the end of exponential growth, after $20 \mathrm{~h}$ of incubation, we analysed the difference in the expression of the stress-related genes (oxyR, sod) between the dark and light groups with or without $\mathrm{H}_{2} \mathrm{O}_{2}$ by qRT-PCR. For WT and mutant cells, regardless of the $\mathrm{H}_{2} \mathrm{O}_{2}$ treatment, red-light illumination led to significant upregulation of the $\operatorname{oxy} R$ gene compared with their dark controls (Fig. 7a, $p<0.01$ ). By contrast, red-light illumination significantly downregulated the expression of sod compared with the dark controls in both the WT cells and the amb2291 mutants (Fig. 7b, $p<0.05$ ). The $\mathrm{H}_{2} \mathrm{O}_{2}$ treatment without red-light illumination had no obvious effect on $\operatorname{oxy} R$ and $\operatorname{sod}$ expression. However, simultaneous red-light illumination and $\mathrm{H}_{2} \mathrm{O}_{2}$ treatment increased the expression of oxyR and sod only in the WT strain (Fig. 7, $p<0.05$ ).

We further examined the involvement of the amb2291 gene in controlling intracellular ROS levels by the DCFH-DA method (Fig. 8). The ROS levels of WT cells under photooxidative stress conditions were significantly lower than those of mutant cells $(p<0.01)$, whereas the ROS level significantly increased $(p<0.01)$ in mutant cells under light irradiation compared with those in the dark. The amb2291 gene helps AMB-1 eliminate intracellular ROS under oxidative stress through the light regulation system.

\section{amb2291 affects the phototactic behaviour under photooxidative stress}

We analysed the difference in the phototactic behaviour in AMB-1 WT cells and mutants. The phototactic behaviour was quantitatively analysed by a modified mini MTB collection vessel as previously described ( $\mathrm{Li}$ et al. 2017). To prevent the difference in phototactic behaviour caused by $\mathrm{H}_{2} \mathrm{O}_{2}$ on the state of bacterial movement, we first examined the speed of bacteria movement under different $\mathrm{H}_{2} \mathrm{O}_{2}$ concentrations. Low $\mathrm{H}_{2} \mathrm{O}_{2}$ concentrations $(10,20,30$, and $40 \mu \mathrm{M})$ exhibited 
insignificant effects on the velocities of AMB-1 WT cells and mutants. However, with increasing $\mathrm{H}_{2} \mathrm{O}_{2}$ concentration, the velocities of all cells showed a consistent downward trend (Fig. S4). Thus, we studied the difference in phototactic behaviour between the WT and mutant strains under 0,10 , and 20 $\mu \mathrm{M} \mathrm{H}_{2} \mathrm{O}_{2}$ treatments.

Phototrophic behaviour was observed only with red light for all three strains analysed. Phototactic behaviour of the mutant strains all decreased with the increasing concentration of $\mathrm{H}_{2} \mathrm{O}_{2}$ (Fig. 9, $p<0.05$ ). Moreover, the photoresponse of WT cells was significantly stronger than that of $\triangle a m b 2291$ or amb2291 ${ }^{A 399 C}$ mutants after adding $\mathrm{H}_{2} \mathrm{O}_{2}$ (Fig. 9, $p<0.05$ ). When $\mathrm{H}_{2} \mathrm{O}_{2}$ was not added, all three strains exhibited a photoresponse. Amb2291 is likely involved in the reduction of the toxicity of $\mathrm{H}_{2} \mathrm{O}_{2}$ to cells and helped WT cells to actively swim towards light.

\section{Discussion}

Flavin-based photoreceptor proteins of the LOV superfamily are ubiquitous in plants, algae, fungi, and prokaryotes (Losi et al. 2015). During photoreaction, the non-covalently bound flavin chromophore forms a covalent adduct with a conserved Cys residue in LOV under blue light to initiate signal transmission to various output domains (Losi 2007). Current studies have reported that some LOV photoreceptors apparently retained biological activity even after the substitution of the Cys thiol for non-reactive side chains (Aihara et al. 2012; Chen et al. 2010; Okajima et al. 2012; Vaidya et al. 2011; Yee et al. 2015). In GenBank, 70 LOV-like proteins contain the strictly conserved LOV domain, except that the adduct-forming Cys is replaced with other residues, including Ala, Pro, Gly and Lys (Yee et al. 2015). In the present study, a group of LOV-like proteins from Magnetospirillum sp. in which the conserved Cys residue is substituted with Ala were reported. The Amb2291 and Amb2291 ${ }^{\mathrm{A} 399 \mathrm{C}}$ mutant proteins in M. magneticum AMB-1 were purified. Accordingly, the pale yellow Amb2291 and Amb2291 ${ }^{\mathrm{A} 399 \mathrm{C}}$ purified from overexpression in E.coli indicate the binding of FMN to the chromophore domains and potential partial reduction of FMN, regardless of the presence or absence of the conserved Cys. Combined with Fig. 2, these results demonstrate the characteristics of LOV-like proteins. Then, we examined the spectral change of Amb2291 and Amb2291 ${ }^{\mathrm{A} 399 \mathrm{C}}$ under blue-light illumination to analyse the photoreaction. Consequently, a faster reaction of Amb2291 ${ }^{\mathrm{A} 399 \mathrm{C}}$ to blue light was observed compared with the WT strain, which shows that Cys is an effective electron donor to the photoexcited 
flavin. Despite of the change in a prolonged illumination studied here cannot be well compared with those in a few minutes, FMN-bound Amb2291 indeed goes through photoreaction as a response to blue light by some mechanism. As the spectrum does not show any change under the same dose of red light (Fig. S5), it demonstrates that the effect of photodamage is negligible. In a conventional LOV photocycle, blue-light absorption drives the formation of a covalent adduct between Cys and flavin, promoting rotation of a conserved glutarnine residue to initiate a cascade of structural rearrangements within the LOV core that are propagated to the domain boundaries (Zoltowski and Gardner 2011) and then generating downstream signalling responses. Signal transduction through flavin photoreduction to the NSQ was recently found to be a general mechanism in natural Cys-less, LOV-like regulators. The WT BAT of $H$. hochstenium shows properties similar to LOV proteins, reducing slowly to the NSQ upon blue-light illumination. However, when the WT BAT is converted to a traditional LOV mechanism by mutating the active-site Pro residue to Cys, the BAT P188C mutant shows a faster reaction to blue-light illumination, appears to the fully reduced HQ with little NSQ intermediate observed in their designed time scale (Yee et al. 2015). Interestingly, the absorption changes measured for Amb2291 and Amb2291 ${ }^{\mathrm{A} 399 \mathrm{C}}$ on exposure to blue light are similar to those of the BAT P188C variant. Although photoreduction of the Cys-less Amb2291 is inefficient, the FMN-bound protein readily undergoes complete chemical reduction to the fully reduced HQ, with little NSQ intermediate observed on the carried-out time scale (Fig. 3a). Moreover, the aromatic residues of phenylalanine and tyrosine close to the FMN-binding domain motif, as revealed in the sequence analysis in Fig. 1, may generate reductive quenching, resulting in a short excited-state life time of Amb2291, which exhibits inefficient photoreduction (Yee et al. 2015).

To analyse the biological functions of amb2291 under photooxidative stress, we used the CRISPR technique to construct $\Delta a m b 2291$ and $a m b 2291^{A 399 C}$ mutants. Growth and magnetosome biosynthesis of AMB-1 WT cells were better than that of $\triangle a m b 2291$ or amb2291 ${ }^{A 399 C}$ mutants. Interestingly, we found that red light protects the WT cells from the deleterious effect of $\mathrm{H}_{2} \mathrm{O}_{2}$-generated oxidative stress, which depends on the function of Amb2291. Dual sensing of blue light and oxidative stress has been observed in $R$. sphaeroides, wherein the blue-light-modulating activity of $R s \mathrm{LOV}$ and $R s \mathrm{AppA}$ is intended to affect photosynthesis and minimize photooxidative damage (Losi et al. 2015; Metz et al. 2012). The structural biochemistry of a fungal LOV photoreceptor reveals an evolutionarily conserved 
pathway that integrates light and oxidative stress (Lokhandwala et al. 2015). To some extent, the light modulating activity of amb2291 affected magnetosome synthesis and minimized photooxidative damage. Red-light irradiation and $\mathrm{H}_{2} \mathrm{O}_{2}$ treatment upregulated the expression of the amb2291 gene. In addition, the expression results in amb2291 deletion strains revealed the autoregulation of the amb2291 gene. Thus, Amb2291 played an important role in photooxidative stress.

Many environmental stimuli, including light, $\mathrm{H}_{2} \mathrm{O}_{2}$, and hyperthermia, generate high levels of ROS that can damage cellular DNA and proteins, perturb the normal redox balance, and cause oxidative stress (Lushchak 2001; Touati 2000). Therefore, organisms have developed methods to protect themselves from ROS, enabling cells to survive oxidative stress. For example, $\operatorname{oxy} R$ and $\operatorname{sod}$ are stress-related genes that regulate the transcription of defence genes via a rapid kinetic reaction in response to oxidative stress (Jo et al. 2015; Lu et al. 2018). In the present study, the expression levels of $\operatorname{oxy} R$ and sod genes were compared between dark and light conditions with or without $\mathrm{H}_{2} \mathrm{O}_{2}$ treatment. Compared with the mutant controls, simultaneous red-light illumination and $\mathrm{H}_{2} \mathrm{O}_{2}$ treatment increased the $\operatorname{oxy} R$ and $\operatorname{sod}$ expression levels only in the WT strains. This result is inconsistent with the expression of $\operatorname{oxy} R$ and sod genes in the WT strains reported by Li et al. (2017), which may be due to the differences among the concentrations of $\mathrm{H}_{2} \mathrm{O}_{2}$ and light treatment. Amb2291 is involved in the regulation of oxidative stress genes and is beneficial for resisting the damage caused by photooxidative stress. A previous study showed that singlet oxygen induces carotenoid biosynthesis in Phaffia rhodozyma and Myxococcus xanthus and is presumed to be light dependent (Hodgson and Murillo 1993; Schroeder and Johnson 1995). Further studies showed that carotenoids can protect bacteria from photooxidative stress damage (Glaeser and Klug 2005). Zeaxanthin accumulates only under photooxidative stress and plays an essential role in protecting the photosynthetic apparatus via the xanthophyll cycle (Demmig-Adams et al. 1999). The Amb2291 protein may also serve the function of both pigments to protect cells from photooxidative stress damage. In addition, the ROS level of WT cells was lower than that of mutant strains under the addion of $\mathrm{H}_{2} \mathrm{O}_{2}$, which is consistent with the notion that light helps AMB-1 cells eliminate intracellular ROS (Li et al. 2017). These findings further provide new evidence that Amb2291 reduces the increase in ROS through light regulation.

AMB-1 exhibited a photoresponse to red light (Fig. 9), which is consistent with our previous study 

amb2291 $1^{A 399 C}$ mutant cells swimming towards light was significantly less than that of the WT cells.

485 This finding might imply that red light under $\mathrm{H}_{2} \mathrm{O}_{2}$ conditions reduced the phototaxis of the mutant, which may be related to the increased cytotoxicity of $\mathrm{H}_{2} \mathrm{O}_{2}$ or ROS in the absence of functional Amb2219. Amb2291 is involved in light regulation to help eliminate ROS under oxidative stress, thereby creating the optimum niche for bacterial growth. It has been shown that $\mathrm{Fe}_{3} \mathrm{O}_{4}$ magnetosomes in MTB exhibit peroxidase-like activity, which can catalyse the photoFenton reaction according to the following equation to scavenge the intracellular levels of ROS (Guo et al. 2012): $\mathrm{Fe}^{2+}+\mathrm{H}_{2} \mathrm{O}_{2}=\mathrm{Fe}^{3+}+$ $\mathrm{HO} \bullet+\mathrm{OH}^{-}$(Goldstein et al. 1993; Touati 2000). Moreover, light irradiation enhances this activity by promoting the synthesis of magnetosome and helps MTB eliminate intracellular ROS (Li et al. 2017). amb2291 expression was significantly increased with red-light irradiation. Moreover, red-light illumination and $\mathrm{H}_{2} \mathrm{O}_{2}$ treatment significantly increased the expression of magnetosome formation genes (mms13, mms6, and $m m s F)$ and antioxidative genes ( $\operatorname{xy} R$ and $s o d)$ in WT cells compared with those in $\triangle a m b 2291$ and $a m b 2291^{A 399 C}$ strains. Therefore, Amb2291 participates in the light-regulated signalling pathway and further enhances the synthesis of magnetosomes and resistance to oxidative damage, which helped clear intracellular ROS, thereby improving phototactic behaviour and bacterial growth.

Collectively, Amb2291 showed a similar LOV spectra based on blue-light irradiation but was unable to undergo the canonical photochemistry of LOV domains with the formation of a flavin-Cys covalent adduct. Upon red-light irradiation, Amb2291 improved the resistance to oxidative stress by some mechanism. Our understanding of the downstream physiological role of LOV protein is far less than that of its biochemical properties, because only several of LOV proteins' roles had been identified (Wu et al. 2013). Whether Amb2291 is directly involved in the red-light response needs further confirmation. We propose the following assumptions. First, structural prediction analysis found that Amb2291 has a specific extra membranous domain, while most LOV domains have no transmembrane structure in general, except the one that is found in the cytoplasm and membrane components in $R$. sphaeroides (Hendrischk et al. 2009). We are not sure whether the specificity of this protein structure plays a role. Second, studies have shown that the red/far-red-light-sensing bacteriophytochrome (BphP) can form an integrated signalling network with LOV in response to red, far-red, and blue light (Wu et al. 2013). 
Strikingly, genomic analysis revealed the presence of BphP protein in AMB-1, named MagBphP, which is a red/far-red photoreceptor that mediates photosensory responses (Brutesco et al. 2017; Wang et al. 2019). We speculate that Amb2291 and the red/far-red-light-induced MagBphP may form an integrated signalling network; one of the biological significances of light-mediated behaviours in AMB-1 is to avoid environmental stress, such as oxidative stress. Fig. 10 shows the functional model of LOV-like Amb2291. The Cys-less LOV-like Amb2291 protein participates in the light-regulated signalling pathway and improves resistance to oxidative damage and magnetic crystal biogenesis in $M$. magneticum. However, the present work does not provide enough data to allow for a conclusion about the mechanism between Amb2291 and MagBphP signalling pathways. In addition, MTB usually live in aquatic environments and navigate towards sediment. They may move to find better living environments that contain trace oxygen through migration towards light (Wang et al. 2019). One of the major challenges that ancient life may have adapted to is ROS. The ancestral role of intracellular magnetosomes may have helped early life cope with oxidative stress through photoresponse (Lin et al. 2020). In short, Amb2291 acts as an LOV-like protein with a complex sensory role when cellular redox state and/or light were functional input signals.

\section{Acknowledgements}

We thank Dandan Li (National Institute of Biological Sciences) for the plasmid of pET28a-His6-SUMO. We greatly appreciate Changyou Chen with the help of useful discussion and suggestions.

\section{Funding information}

This work was supported by the State Key Program of National Natural Science of China (Grant No. 51937011) and the Research Project Funded by the Institute of Electrical Engineering, Chinese Academy of Sciences (grant number Y650141CSA).

\section{Compliance with ethical standards}

Conflict of interests The authors declare that they have no conflict of interest.

Ethical approval This article does not contain any studies with human participants or animals performed by any of the authors. 


\section{References}

Akbar S, Gaidenko TA, Kang CM, O'Reilly M, Devine KM, Price CW (2001) New family of regulators in the environmental signaling pathway which activates the general stress transcription factor $\sigma^{\mathrm{B}}$ of Bacillus subtilis. J. Bacteriol 183(4):1329-1338. http://doi.org/10.1128/JB.183.4.13291338.2001

Aihara Y, Yamamoto T, Okajima K, Yamamoto K, Suzuki T, Tokutomi S, Tanaka K, Nagatani A (2012) Mutations in N-terminal flanking region of blue light-sensing light-oxygen and voltage 2 (LOV2) domain disrupt its repressive activity on kinase domain in the Chlamydomonas phototropin. J Biol Chem 287(13):9901-9909. http://doi.org/10.1074/jbc.M111.324723

Braatsch S, Klug G (2004) Blue light perception in bacteria. Photosynth Res 79(1):45-57. http://doi.org/10.1023/B:PRES.0000011924.89742.f9

Brutesco C, Prévéral S, Escoffier C, Descamps EC, Prudent E, Cayron J, Garcia, D (2017). Bacterial host and reporter gene optimization for genetically encoded whole cell biosensors. Environ Sci Pollut Res Int 24(1) :52-65. http://doi.org/10.1007/s11356-016-6952-2

Briggs WR (2007) The LOV domain: a chromophore module servicing multiple photoreceptors. J Biomed Sci 14(4):499-504. http://doi.org/10.1007/s11373-007-9162-6

Chen C-H, DeMay BS, Gladfelter AS, Dunlap JC, Loros JJ (2010) Physical interaction between VIVID and white collar complex regulates photoadaptation in Neurospora. Pro Natl Acad Sci U S A 107(38):16715-16720. http://doi.org/10.1073/pnas.1011190107

Chen CF, Ma QF, Jiang W, Song T (2011) Phototaxis in the magnetotactic bacterium Magnetospirillum magneticum strain AMB-1 is independent of magnetic fields. Appl Microbiol Biotechnol 90(1):269-275. http://doi.org/10.1007/s00253-010-3017-1

Chen HT, Zhang S-D, Chen LJ, Cai Y, Zhang W-J, Song T, Wu L-F (2018) Efficient genome editing of Magnetospirillum magneticum AMB-1 by CRISPR-Case9 system for analyzing magnetotactic behavior. Front Microbiol 9:1569-1581. http://doi.org/10.3389/fmicb.2018.01569

Christie JM, Salomon M, Nozue K, Wada M, Briggs WR (1999) LOV (light, oxygen, or voltage) domains of the blue-light photoreceptor phototropin (nph1): binding sites for the chromophore flavin mononucleotide. Proc Natl Acad Sci U S A 96(15):8779-8783. http://doi.org/10.1073/pnas.96.15.8779

Cobb RE, Wang Y, Zhao H (2015) High-efficiency multiplex genome editing of Streptomyces species 
using an engineered CRISPR/Cas system. ACS Synth Biol 4(6):723-728. http://do.org/10.1021/sb500351f

de Melo RD, Acosta-Avalos D (2017) Light effects on the multicellular magnetotactic prokaryote 'Candidatus Magnetoglobus multicellularis' are cancelled by radiofrequency fields: the involvement of radical pair mechanisms. Antonie van Leeuwenhoek 110(2):177-186. http://doi.org/10.1007/s10482-016-0788-0

Demmig-Adams B, Adams WW, Ebbert V, Logan BA (1999) Ecophysiology of the xanthophyll cycle. In: Frank H.A., Young A.J., Britton G., Cogdell R.J. (eds) The Photochemistry of Carotenoids. Adv Photosynth Respir 8:245-269. https://doi.org/10.1007/0-306-48209-6_14

Endres S, Granzin J, Circolone F, Stadler A, Krauss U, Drepper T, Svensson V, Knieps-Grunhagen E, Wirtz A, Cousin A, Tielen P, Willbold D, Jaeger KE, Batra-Safferling R (2015) Structure and function of a short LOV protein from the marine phototrophic bacterium Dinoroseobacter shibae. BMC Microbiol 15(30). http://doi.org/10.1186/s12866-015-0365-0

Faivre D, Schuler D (2008) Magnetotactic bacteria and magnetosomes. Chem Rev 108(11):4875-4898. http://doi.org/10.1021/cr078258w

Fedorov R, Schlichting I, Hartmann E, Domratcheva T, Fuhrmann M, Hegemann P (2003) Crystal structures and molecular mechanism of a light-induced signaling switch: The Phot-LOV1 domain from Chlamydomonas reinhardtii. Biophysical Journal 84(4):2474-2482 http://doi.org/10.1016/s0006-3495(03)75052-8

Frankel RB, Blakemore RP (1989) Magnetite and magnetotaxis in microorganisms. Bioelectromagnetics 10(3):223-237. https://doi.org/10.1002/bem.2250100303

Glaeser J, Klug G (2005) Photo-oxidative stress in Rhodobacter sphaeroides: protective role of carotenoids and expression of selected genes. Microbiology 151(Pt 6):1927-1938. http://doi.org/10.1099/mic.0.27789-0

Goldstein S, Meyerstein D, Czapski G (1993) The fenton reagents. Free Radical Biol Med 15(4):435-445. http://doi.org/10.1016/0891-5849(93)90043-t

Guo FF, Yang W, Jiang W, Geng S, Peng T, Li JL (2012) Magnetosomes eliminate intracellular reactive oxygen species in Magnetospirillum gryphiswaldense MSR-1. Environ Microbiol 14(7):1722-1729. http://doi.org/10.1111/j.1462-2920.2012.02707.x

He YY, Hader DP (2002) Involvement of reactive oxygen species in the UV-B damage to the 
cyanobacterium Anabaena sp. J Photochem Photobiol B 66(1):73-80. https://doi.org/10.1016/S1011-1344(01)00278-0

Hendrischk AK, Moldt J, Frühwirth SW, Klug G (2009) Characterization of an unusual LOV domain protein in the $\alpha$-Proteobacterium Rhodobacter sphaeroides. Photochem Photobiol 85(5):1254-1259. https://doi.org/10.1111/j.1751-1097.2009.00554.X

Hodgson D, Murillo FJ (1993) Genetics of regulation and pathway of synthesis of carotenoids. Myxobacteria II. American Society for Microbiology, Washington, pp 157-181.

Jo I, Chung IY, Bae HW, Kim JS, Song S, Cho YH, Ha NC (2015) Structural details of the OxyR peroxide-sensing mechanism. Proc Natl Acad Sci U S A 112(20):6443-6448. http://doi.org/10.1073/pnas.1424495112

Kim HS, Willett JW, Jain-Gupta N, Fiebig A, Crosson S (2014) The Brucella abortus virulence regulator, LovhK, is a sensor kinase in the general stress response signalling pathway. Mol Microbiol 94(4):913-925. http://doi.org/10.1111/mmi.12809

Komeili A (2007) Molecular mechanisms of magnetosome formation. Annu Rev Biochem 76:351-366. http://doi.org/10.1146/annurev.biochem.74.082803.133444

Komeili A (2012) Molecular mechanisms of compartmentalization and biomineralization in $\begin{array}{llll}\text { magnetotactic } & \text { bacteria. } & \text { FEMS }\end{array}$ https://doi.org/10.1111/j.1574-6976.2011.00315.x

Li DD, Wang JL, Jin ZC, Zhang Z (2019) Structural and evolutionary characteristics of dynamin-related GTPase OPA1. Peer J 7:e7285. http://doi.org/10.7717/peerj.7285

Li KF, Wang PP, Chen CF, Chen CY, Li LL, Song T (2017) Light irradiation helps magnetotactic bacteria eliminate intracellular reactive oxygen species. Environ Microbiol 19(9):3638-3648 http://doi.org/10.1111/1462-2920.13864

Livak KJ, Schmittgen TD (2001) Analysis of relative gene expression data using real-time quantitative PCR and the $2^{-\Delta \Delta C T}$ method. Methods 25(4):402-408. http://doi.org/10.1006/meth.2001.1262

Lin W, Kirschvink JL, Paterson GA, Bazylinski DA, Pan YX (2020) On the origin of microbial magnetoreception. Nat Sci Rev 7(2):472-479. http://doi.org/10.1093/nsr/nwz065

Lokhandwala J, Hopkins HC, Rodriguez-Iglesias A, Dattenbock C, Schmoll M, Zoltowski BD (2015) Structural biochemistry of a fungal LOV domain photoreceptor reveals an evolutionarily conserved pathway integrating light and oxidative stress. Structure 23(1):116-125 
http://doi.org/10.1016/j.str.2014.10.020

Losi A (2007) Flavin-based blue-light photosensors: a photobiophysics update. Photochem Photobiol 83(6):1283-1300. http://doi.org/10.1111/j.1751-1097.2007.00196.x

Losi A, Mandalari C, Gartner W (2015) The evolution and functional role of flavin-based prokaryotic photoreceptors. Photochem Photobiol 91(5):1021-31. http://doi.org/10.1111/php.12489

Losi A, Polverini E, Quest B, Gartner W (2002) First evidence for phototropin-related blue-light $\begin{array}{lllll}\text { receptors in } & \text { prokaryotes. }\end{array}$ http://doi.org/10.1016/s0006-3495(02)75604-x

Lu Z, Sethu R, Imlay JA (2018) Endogenous superoxide is a key effector of the oxygen sensitivity of a model obligate anaerobe. Proc Natl Acad Sci U S A 115(14):E3266-E3275. http://doi.org/10.1073/pnas.1800120115

Lushchak VI (2001) Oxidative stress and mechanisms of protection against it in bacteria. Biochemistry (Mosc) 66(5):476-489. https://doi.org/10.1023/A:1010294415625

Matsunaga T, Okamura Y, Fukuda Y, Wahyudi AT, Murase Y, Takeyama H (2005) Complete genome sequence of the facultative anaerobic magnetotactic bacterium Magnetospirillum sp. strain AMB-1. DNA Res 12(3):157-166. https://doi.org/10.1093/dnares/dsi002

Matsunaga T, Sakaguchi T, Tadokoro F (1991) Magnetite formation by a magnetic bacterium capable of growing aerobically. Appl Microbiol Biotechnol 35(5):651-655. https://doi.org/10.1007/BF00169632

Meijering E, Dzyubachyk O, Smal I (2012) Methods for cell and particle tracking. In: Conn PM (ed) Imaging and spectroscopic analysis of living cells: Optical and spectroscopic techniques. Methods in Enzymology. Elsevier Academic Press Inc, San Diego, pp 183-200

Metz S, Jager A, Klug G (2012) Role of a short light, oxygen, voltage (LOV) domain protein in blue light and singlet oxygen-dependent gene regulation in Rhodobacter sphaeroides. Microbiology 158(Pt 2):368-379. http://doi.org/10.1099/mic.0.054700-0

Murat D, Herisse M, Espinosa L, Bossa A, Alberto F, Wu LF (2015) Opposite and coordinated rotation of amphitrichous flagella governs oriented swimming and reversals in a magnetotactic spirillum. J Bacteriol 197(20):3275-3282. http://doi.org/10.1128/jb.00172-15

O'Donoghue B, NicAogain K, Bennett C, Conneely A, Tiensuu T, Johansson J, O'Byrne C (2016) Blue-light inhibition of listeria monocytogenes growth is mediated by reactive oxygen Species and 
is influenced by $\sigma \mathrm{B}$ and the blue-light sensor Lmo0799. Appl Environ Microbiol 82(13):4017-4027. http://doi.org/10.1128/aem.00685-16

Okajima K, Kashojiya S, Tokutomi S (2012) Photosensitivity of kinase activation by blue light involves the lifetime of a cysteinyl-flavin adduct intermediate, S390, in the photoreaction cycle of the LOV2 domain in phototropin, a plant blue light receptor. J Biol Chem 287(49):40972-40981. http://doi.org/10.1074/jbc.M112.406512

Philippe N, Wu L-F (2010) An MCP-like protein interacts with the MamK cytoskeleton and is involved in magnetotaxis in Magnetospirillum magneticum AMB-1. J Mol Biol 400(3):309-322. http://doi.org10.1016/j.jmb.2010.05.011

Pudasaini A, El-Arab KK, Zoltowski BD (2015) LOV-based optogenetic devices: light-driven modules to impart photoregulated control of cellular signaling. Front Mol Biosci 2:18. http://doi.org/10.3389/fmolb.2015.00018

Pudasaini A, Shim JS, Song YH, Shi H, Kiba T, Somers DE, Imaizumi T, Zoltowski BD (2017) Kinetics of the LOV domain of ZEITLUPE determine its circadian function in Arabidopsis. Elife 6:e21646. http://doi.org/10.7554/eLife.21646

Purcell EB, Crosson S (2008) Photoregulation in prokaryotes. Curr Opin Microbiol 11(2):168-178 http://doi.org/10.1016/j.mib.2008.02.014

Purcell EB, McDonald CA, Palfey BA, Crosson S (2010) An analysis of the solution structure and signaling mechanism of LovK, a sensor histidine kinase integrating light and redox signals. Biochemistry 49(31):6761-6770. http://doi.org/10.1021/bi1006404

Qian XX, Santini CL, Kosta A, Menguy N, Le Guenno H, Zhang WY, Li JH, Chen YR, Liu J, Alberto F, Espinosa L, Xiao T, Wu LF (2019) Juxtaposed membranes underpin cellular adhesion and display unilateral cell division of multicellular magnetotactic prokaryotes. Environ Microbiol 22(4):1481-1494. http://doi.org/10.1111/1462-2920.14710

Salomon M, Christie JM, Knieb E, Lempert U, Briggs WR (2000) Photochemical and mutational analysis of the FMN-binding domains of the plant blue light receptor, phototropin. Biochemistry 39(31):9401-9410. http://doi.org/10.1021/bi000585+

Schroeder WA, Johnson EA (1995) Singlet oxygen and peroxyl radicals regulate carotenoid biosynthesis in Phaffia rhodozyma. J Biol Chem 270(31):18374-18379. http://doi.org/10.1074/jbc.270.31.18374 
Schüler D, Rainer U, Bäuerlein E (1995) A simple light-scattering method to assay magnetism in Magnetospirillum gryphiswaldense. FEMS Microbiol Lett 132(1-2):139-145. https://doi.org/10.1111/j.1574-6968.1995.tb07823.x

Shapiro OH, Hatzenpichler R, Buckley DH, Zinder SH, Orphan VJ (2011) Multicellular photo-magnetotactic bacteria. Environ Microbiol Rep 3(2):233-238. http://doi.org10.1111/j.1758-2229.2010.00215.x

Spring S, Bazylinski DA (2006) Magnetotactic Bacteria. In: Dworkin M, Falkow S, Rosenberg E, Schleifer KH, Stackebrandt E (eds) The Prokaryotes. Springer, New York, pp 842-862

Spudich JL (2006) The multitalented microbial sensory rhodopsins. Trends Microbiol 14(11):480-487. http://doi.org/10.1016/j.tim.2006.09.005

Taylor BL, Zhulin IB (1999) PAS domains: internal sensors of oxygen, redox potential, and light. Microbiol Mol Biol Rev 63(2):479-506.

Touati D (2000) Iron and oxidative stress in bacteria. Arch Biochem Biophys 373(1):1-6. http://doi.org/10.1006/abbi.1999.1518

Vaidya AT, Chen CH, Dunlap JC, Loros JJ, Crane BR (2011) Structure of a light-activated LOV protein dimer that regulates transcription. Sci Signaling 4(184):ra50. http://doi.org/10.1126/scisignal.2001945

Wang YZ, Lin W, Li JH, Pan YX (2013) Changes of cell growth and nnagnetosonne biomineralization in Magnetospirillum magneticum AMB-1 after ultraviolet-B irradiation. Front Microbiol 4:10. http://doi.org/10.3389/fmicb.2013.00397

Wang YZ, Casaburi G, Lin W, Li Y, Wang FP, Pan YX (2019). Genomic evidence of the illumination response mechanism and evolutionary history of magnetotactic bacteria within the Rhodospirillaceae family. BMC genomics 20(1): 407. https://oi.org/10.1186/s12864-019-5751-9

Wilde A, Mullineaux CW (2017) Light-controlled motility in prokaryotes and the problem of directional light perception. FEMS Microbiol Rev 41(6):900-922. http://doi.org/10.1093/femsre/fux045

Wu L, McGrane RS, Beattie GA (2013) Light regulation of swarming motility in Pseudomonas syringae integrates signaling pathways mediated by a bacteriophytochrome and a LOV protein. Mbio 4(3):e00334-13. http://doi.org/10.1128/mBio.00334-13

Xie SS, Shen B, Zhang CB, Huang XX, Zhang YL (2014) sgRNAcas9: a software package for 
designing CRISPR sgRNA and evaluating potential off-target cleavage sites. Plos One 9(6):e100448. http://doi.org/10.1371/journal.pone.0100448

Yang CD, Takeyama H, Tanaka T, Matsunaga T (2001) Effects of growth medium composition, iron sources and atmospheric oxygen concentrations on production of luciferase-bacterial magnetic particle complex by a recombinant Magnetospirillum magneticum AMB-1. Enzyme Microb Technol 29(1):13-19. https://doi.org/10.1016/S0141-0229(01)00343-X

Yee EF, Diensthuber RP, Vaidya AT, Borbat PP, Engelhard C, Freed JH, Bittl R, Moeglich A, Crane BR (2015) Signal transduction in light-oxygen-voltage receptors lacking the adduct-forming cysteine residue. Nat Commun 6:10079. doi:10.1038/ncomms10079

Zhang W-J, Zhang S-D, Wu L-F (2017) Measurement of free-swimming Mmotility and magnetotactic behavior of Magnetococcus massalia strain MO-1. Methods mol biol. Humana Press, New York, NY. http://doi.org/10.1007/978-1-4939-6927-2_25

Zhao LZ, Wu D, Wu L-F, Song T (2007) A simple and accurate method for quantification of magnetosomes in magnetotactic bacteria by common spectrophotometer. J Biochem Biophys Methods 70(3):377-383. http://doi.org/10.1016/j.jbbm.2006.08.010

Zhou K, Pan HM, Zhang S-D, Yue H, Xiao T, Wu L-F (2011) Occurrence and microscopic analyses of multicellular magnetotactic prokaryotes from coastal sediments in the Yellow Sea. Chin J Oceanol Limnol 29(2):246-251. http://doi.org/10.1007/s00343-011-0032-8

Zoltowski BD, Gardner KH (2011) Tripping the light fantastic: blue-light photoreceptors as examples of environmentally modulated protein-protein interactions. Biochemistry 50(1):4-16 http://doi.org/10.1021/bi101665s

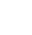


a

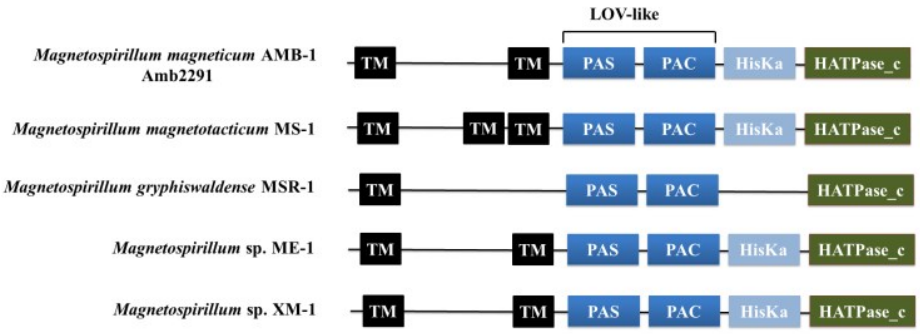

b

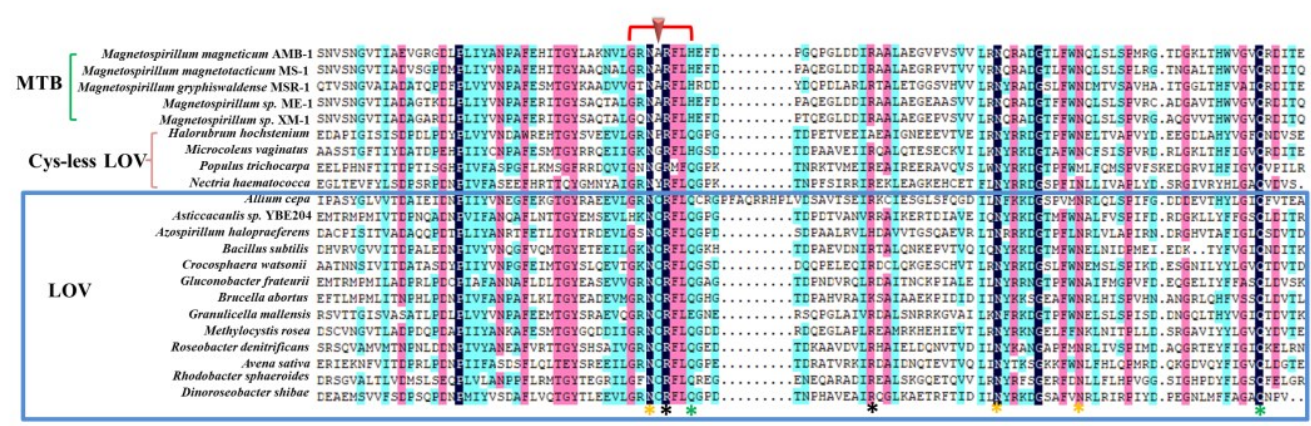

Fig. 1 Domain structures and amino acid sequence alignment of LOV proteins. a Domain structures of Amb2291 and other LOV-like proteins of MTB. TM, transmembrane segment; PAS, Per-Arnt-Sim domain; PAC, motif C-terminal to PAS motifs; HisKa, histidine kinase domain; HATPase, histidine kinase-like ATPase; The PAS-PAC domain is similar to LOV. b Alignment of selected LOV domains of MTB and similar regions of other Cys-less or LOV proteins. The red brace shows a conserved motif in LOV. The red triangle indicates the position of the conserved Cys involved in photoactivated FMN covalent binding.* Black shows the Arg residues that interact with the phosphate moiety of the flavin,

$762 *$ yellow shows the Asn residues that interact with the polar side of the isoalloxazine ring, and *green shows the Gln residues related to signalling. 
a

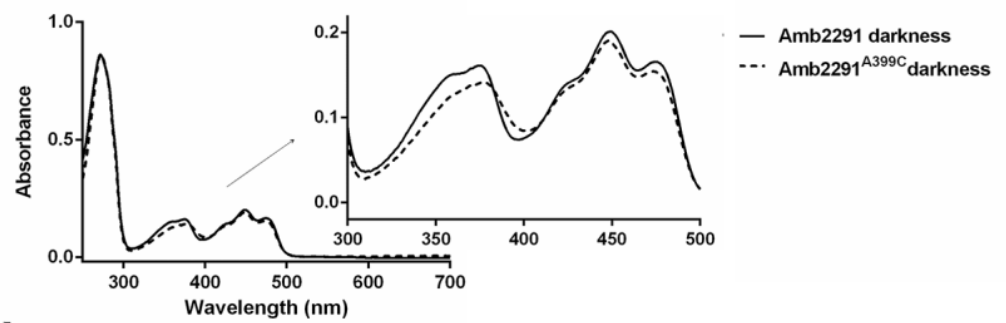

b

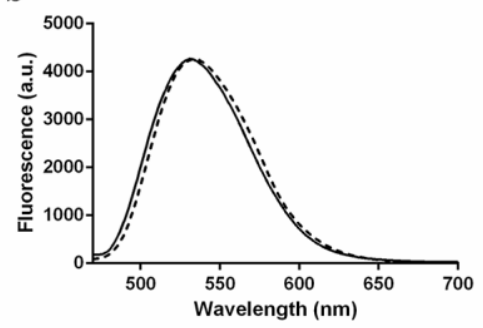

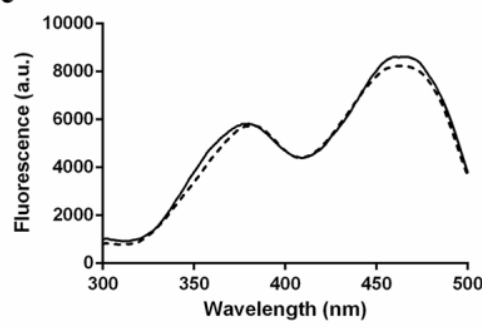

764

765 Fig. 2 Spectral properties of purified Amb2291 and Amb2291 ${ }^{\text {A399C }}$ proteins. a Absorption spectra of Amb2291 (solid line) and Amb2291 ${ }^{\mathrm{A} 399 \mathrm{C}}$ (dashed line) in the dark. b Fluorescence emission spectra for

767 Amb2291 and Amb2291 ${ }^{\mathrm{A} 399 \mathrm{C}}$. Fluorescence excitation was monitored at $450 \mathrm{~nm}$. c Fluorescence excitation spectra for Amb2291 and Amb2291 ${ }^{\mathrm{A} 399 \mathrm{C}}$. Emission was at $530 \mathrm{~nm}$. 

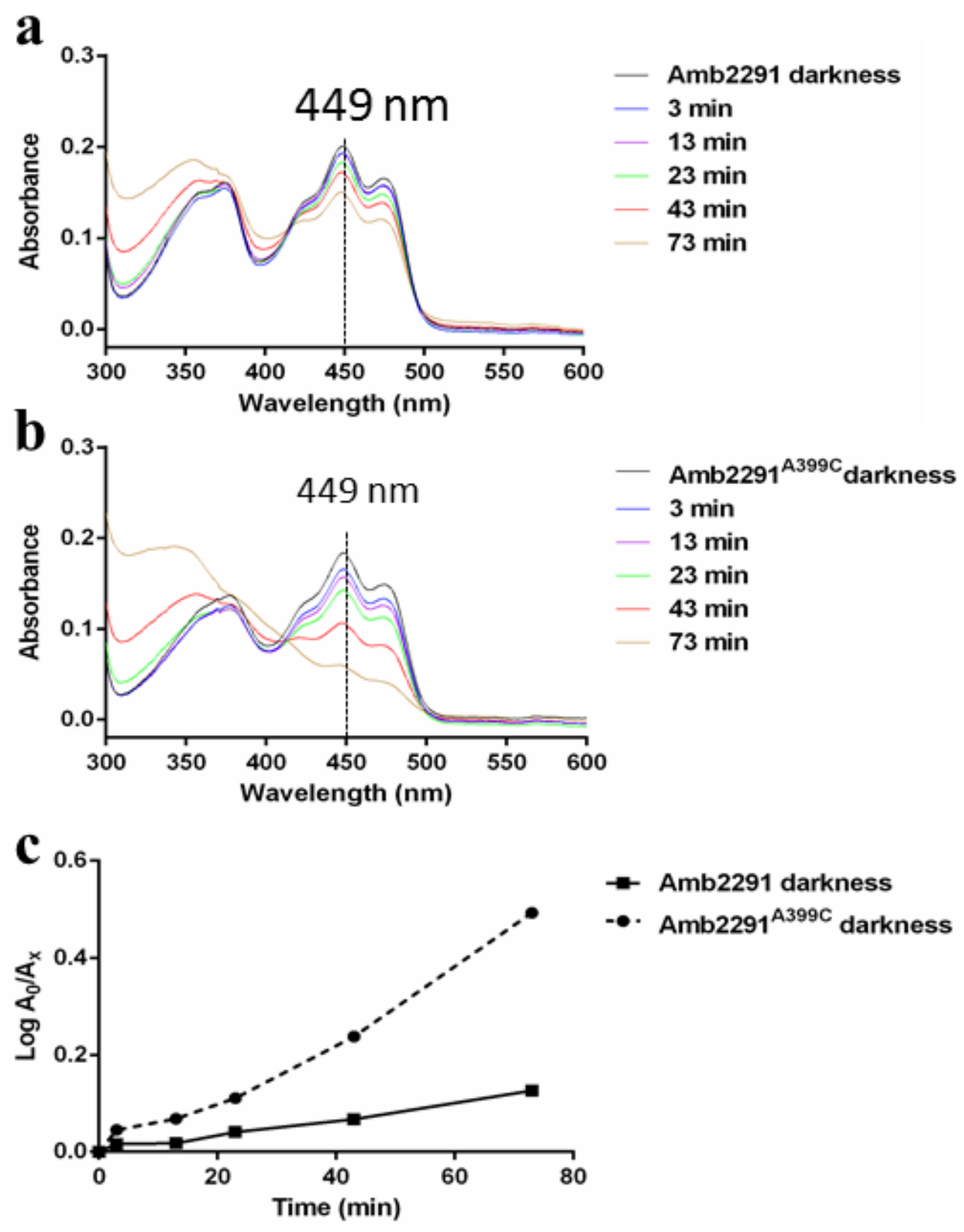

770 Fig. 3 Photoreduction of purified Amb2291 and Amb2291 ${ }^{\mathrm{A} 399 \mathrm{C}}$ proteins by blue-light irradiation.

771 Absorbance changes measured for Amb2291 (a) and Amb2291 ${ }^{\mathrm{A} 399 \mathrm{C}}(\mathbf{b})$ on exposure to high-intensity

772 blue light $\left(1700 \mu \mathrm{mol}\right.$ photons $\left./ \mathrm{m}^{2} / \mathrm{s}\right)$. $\mathbf{c}$ The kinetic data were obtained by following the absorbance

773 changes at $449 \mathrm{~nm}$ for Amb2291 and Amb2291 ${ }^{\mathrm{A} 399 \mathrm{C}}$ proteins. $\mathrm{A}_{0}$ represents the amount of unreacted

774 flavoprotein at time zero. $A_{x}$ represents the corresponding amount of unreacted flavoprotein at time $x$. 


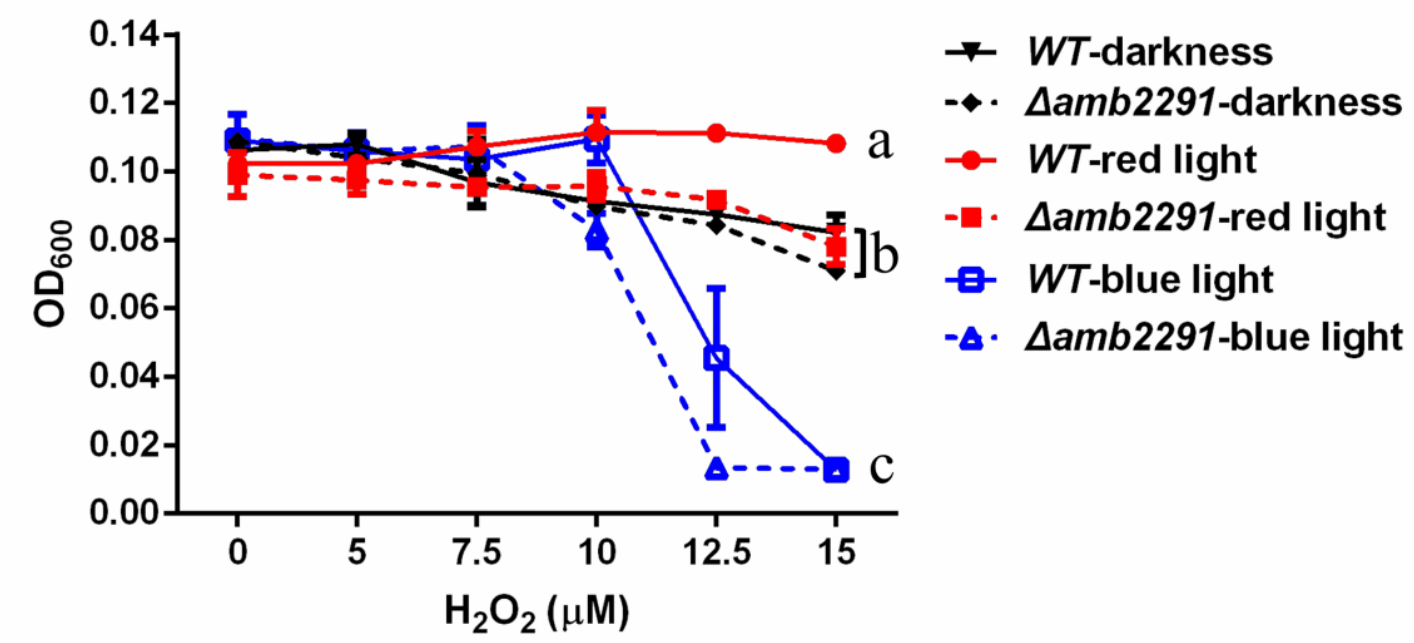

775

Fig. 4 Evaluation of the $\mathrm{H}_{2} \mathrm{O}_{2}$-generated oxidative stress effect on AMB-1 cells. The OD values of AMB-1 WT cells (solid lines) and $\Delta a m b 2291$ mutant (dashed lines) under irradiation or in the dark at different concentrations of $\mathrm{H}_{2} \mathrm{O}_{2}$ were the average of four independent experiments with standard deviations (error bars). The OD values are grouped into $\mathrm{a}, \mathrm{b}$, and $\mathrm{c}$ using the HCA method.

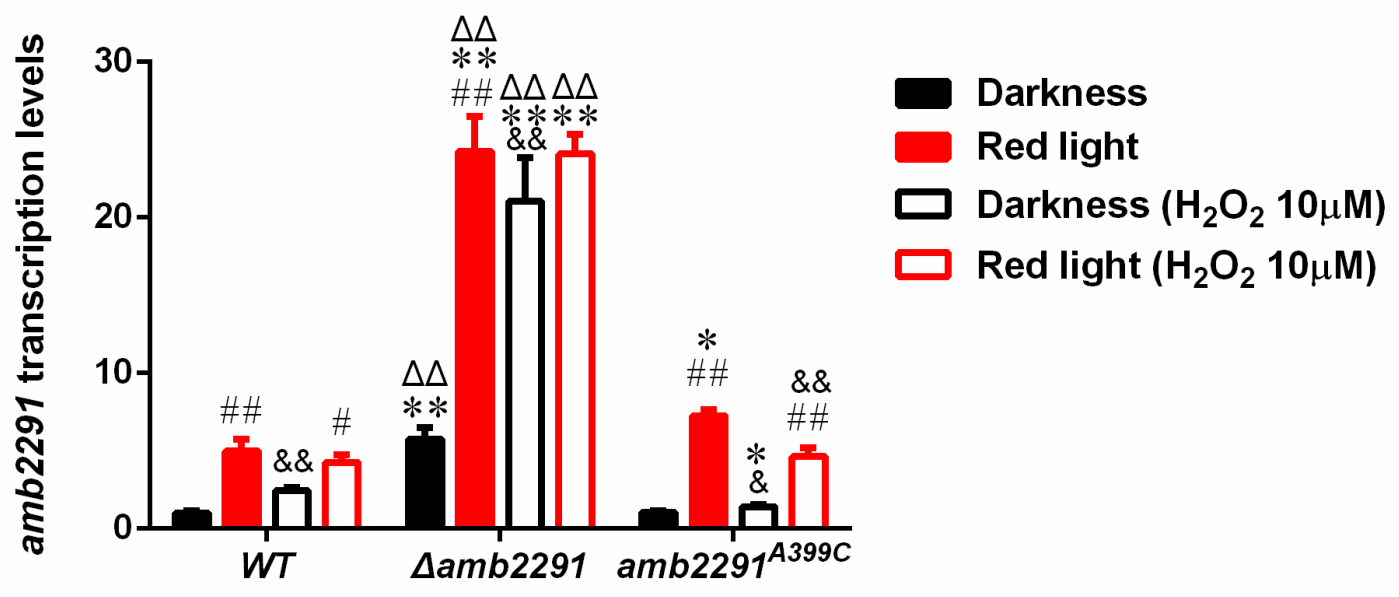

Fig. 5 Relative expression levels of the residual amb2291 gene determined via qRT-PCR under red light and/or by adding $\mathrm{H}_{2} \mathrm{O}_{2}$ to the medium $(n=3)$. \# represents the statistical analyses performed between red light and dark. \& shows the statistical analyses between the $\mathrm{H}_{2} \mathrm{O}_{2}$ group and their respective normal controls. ${ }^{*}$ describes the statistical analyses between the mutants and WT control. $\Delta$ shows the statistical analyses between $\triangle a m b 2291$ and $a m b 2291^{A 399 C}$ mutant cells. 

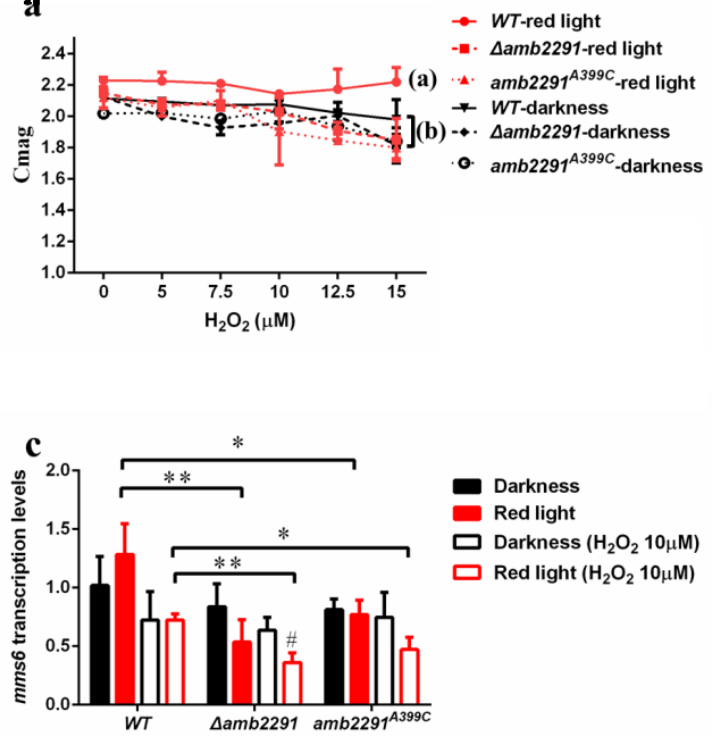
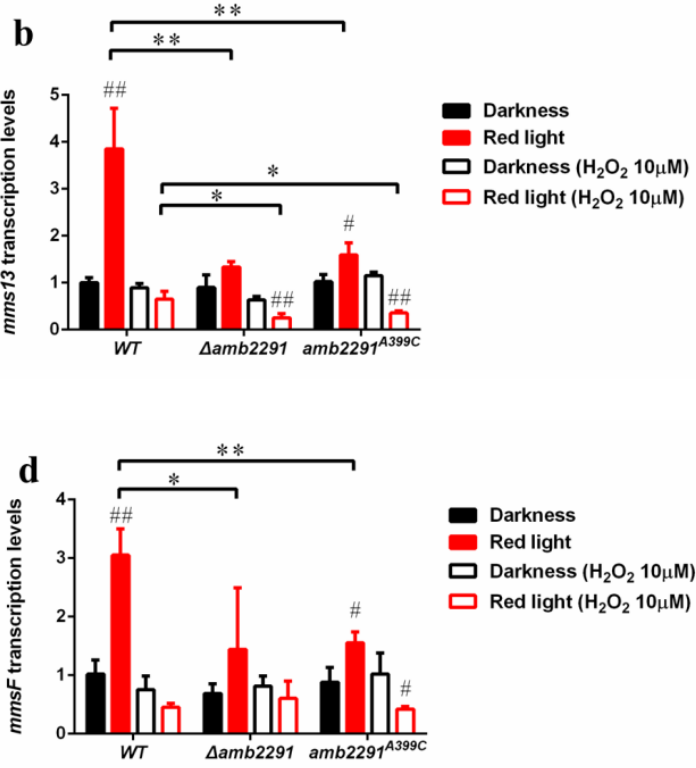

787

Fig. 6 Effects of amb2291 deletion or mutant on magnetosome formation under photooxidative stress conditions. a Value of Cmag under red-light irradiation or dark at different concentrations of $\mathrm{H}_{2} \mathrm{O}_{2}$ in AMB-1 cells $(n=4)$. The Cmag of each group is shown and analysed using HCA. Relative expression levels of $m m s 13$ (b), mms 6 (c), and $m m s F$ (d) determined via qRT-PCR under red light and/or by adding $\mathrm{H}_{2} \mathrm{O}_{2}$ to the medium ( $n=3$ ). Level of significance of the differences observed between light and dark control is expressed as hashtag sign ( $\# p<0.05$ and $\# \# p<0.01$ ). The significant differences between the two groups depicted by the lines in the graph are indicated by one or two asterisks $(* p<0.05$, $* * p<0.01)$.
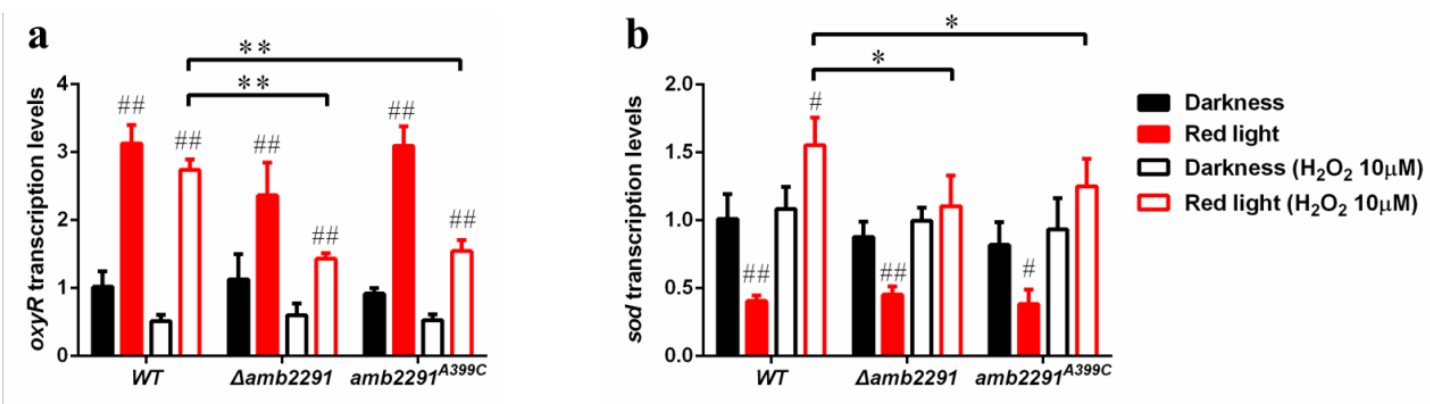

Fig. 7 Relative expression levels of $\operatorname{oxy} \mathrm{R}$ (a) and $\operatorname{sod}(\mathbf{b})$ genes determined under red light and/or by adding $\mathrm{H}_{2} \mathrm{O}_{2}$ in the medium ( $n=3$ ). The level of significance of the differences observed between light and dark control is expressed as hashtag sign $(\# p<0.05$ and $\# \# p<0.01)$. The significant differences 
801

802 $(* p<0.05, * * p<0.01)$.
803

804

805

806

807

808

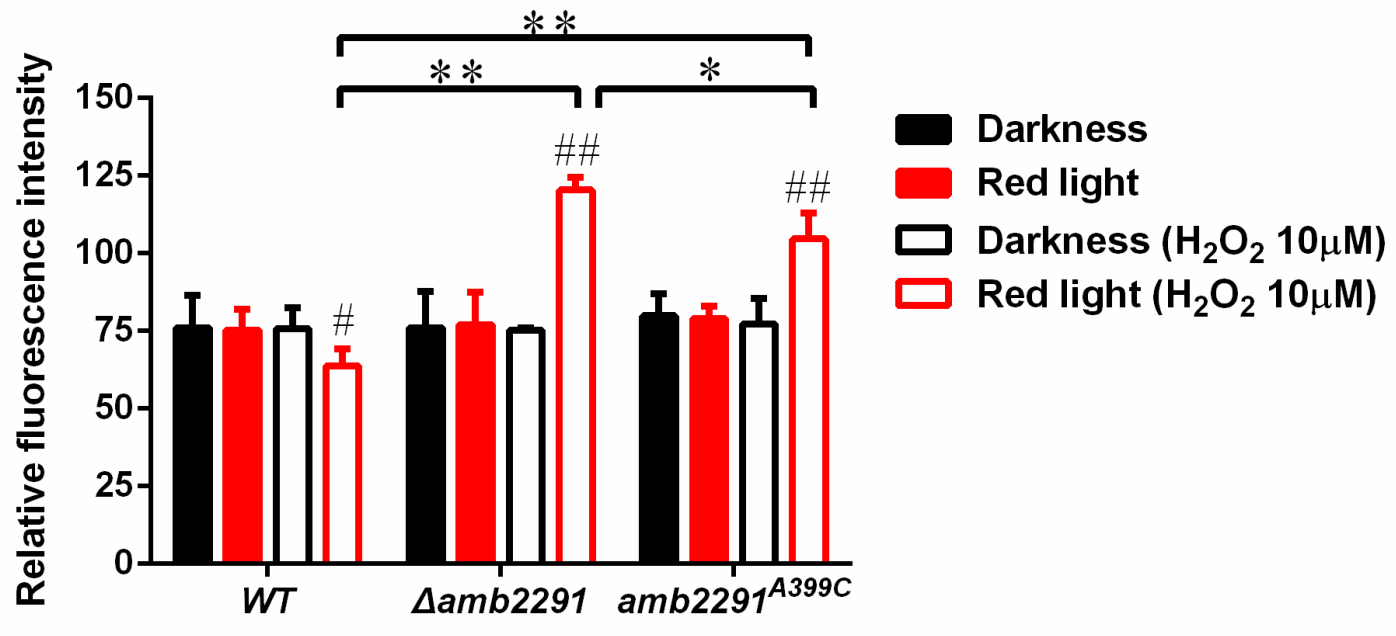

Fig. 8 Effects of Amb2291 on intracellular ROS level in AMB-1 cells ( $n=6)$. The level of significance of the differences observed between the light and dark control is expressed as hashtag sign ( $\# p<0.05$ and $\# \# p<0.01)$. The significant differences between the two groups depicted by the lines in the graph are indicated by one or two asterisks $(* p<0.05, * * p<0.01)$.

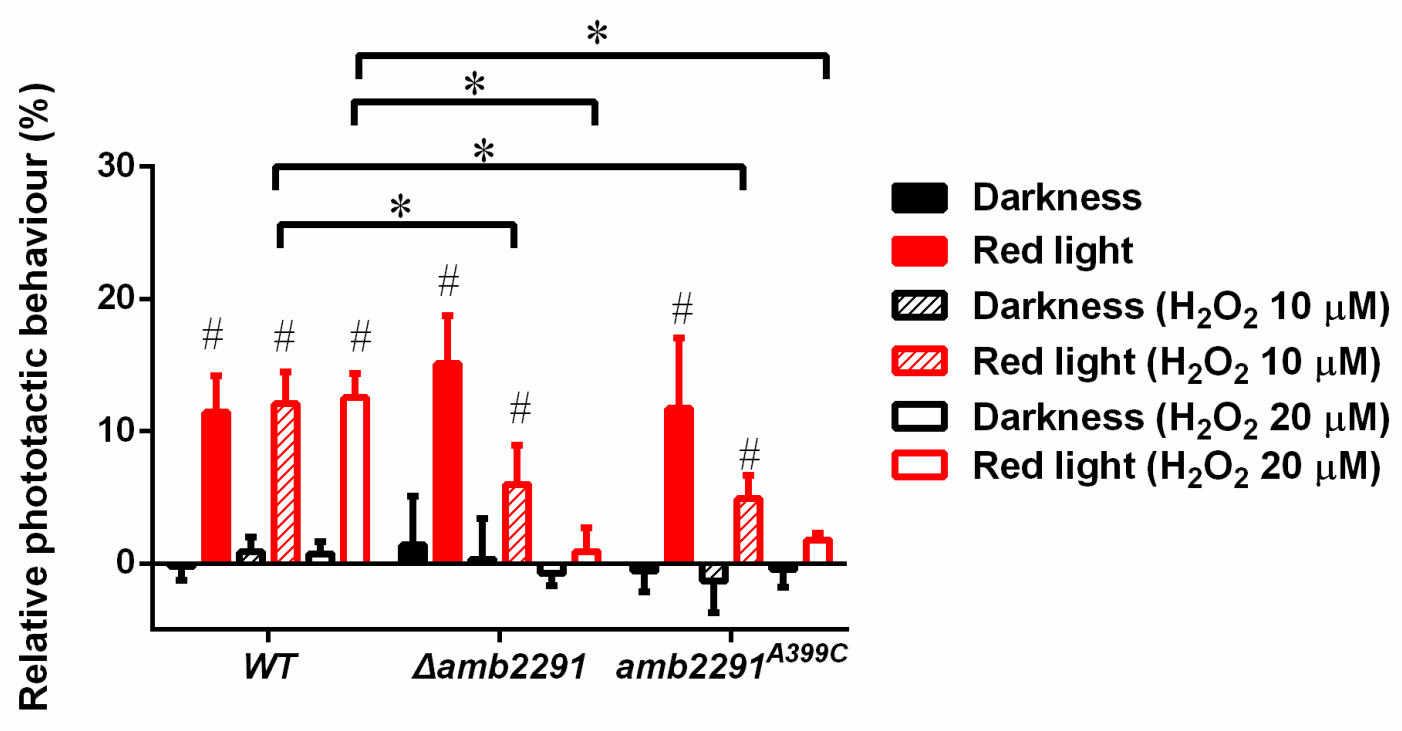

809

Fig. 9 Effects of amb2291 deletion or site-directed mutagenesis on the phototactic behaviour of AMB-1 cells. Relative phototactic behaviour (\%) of the WT and mutant strains ( $n=4)$. Level of the significance of the differences observed between light and dark control is expressed as a hashtag sign $(\# p<0.05)$. The significant differences between the two groups depicted by the lines in the graph are 


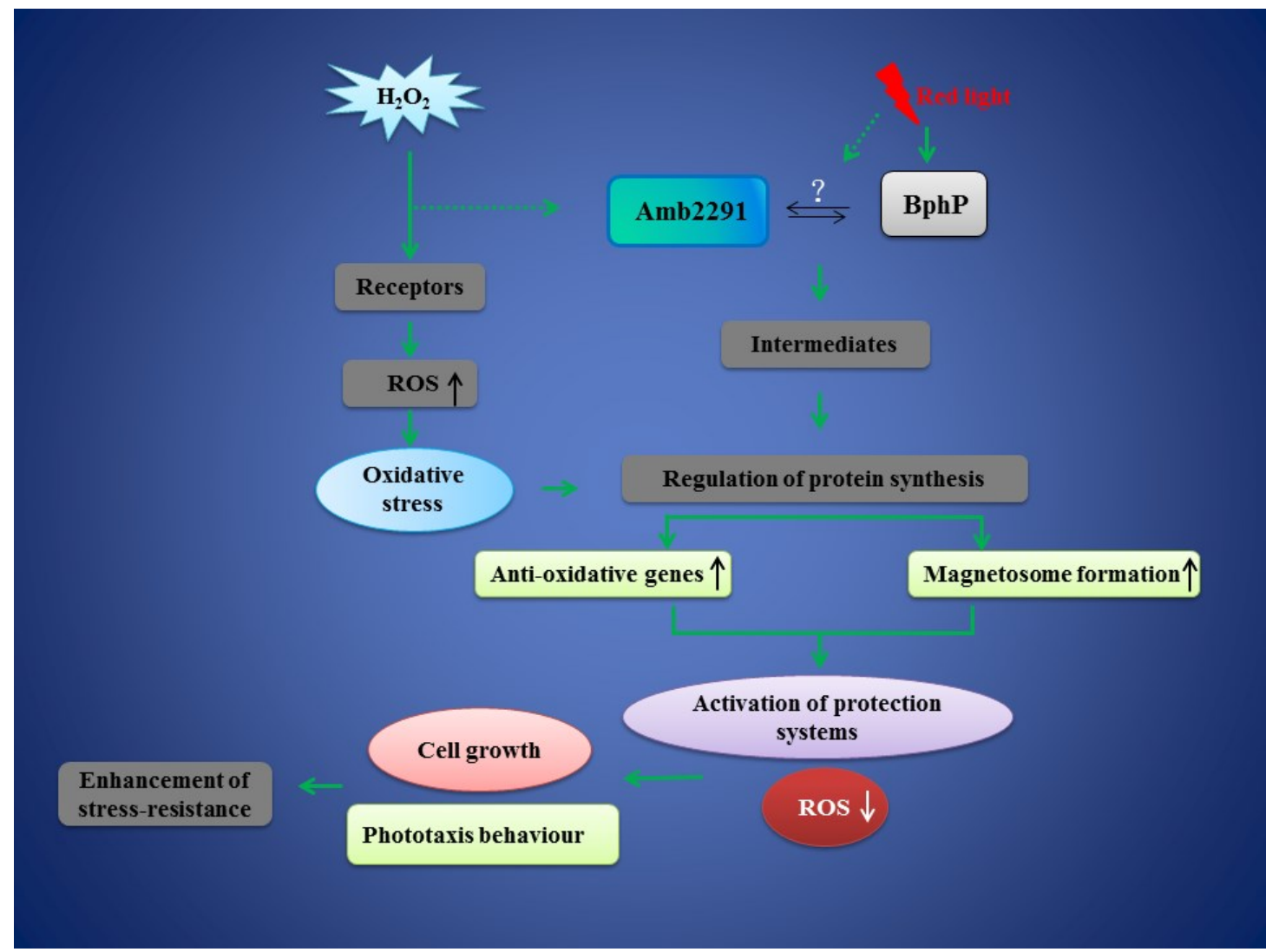

816 Fig. 10 Functional model of LOV-like Amb2291 protein. Red-light illumination and oxidative stress

817 can regulate the LOV-like protein Amb2291 to enhance the expression levels of antioxidant genes and 818 stimulate the formation of magnetosomes and then reduce intracellular ROS levels. The general 819 function is to protect magnetotactic bacteria (MTB) cells from the deleterious effects of oxidative stress.

820 The arrows show the red-light signal transduction pathway; Amb2291 may interact with $821 \mathrm{red} /$ far-red-light-induced bacteriophytochrome $(\mathrm{BphP})$ by some mechanisms to form the signalling 822 network response to red light. The signal transduction intermediates can be anti-oxidative genes, such as $\operatorname{oxy} R$ and $\operatorname{sod}$, and magnetosome, the magnetite crystal in MTB. 